\title{
ALIEN SPECIES IN LOCAL FLORAS \\ OF THE VORONEZH REGION NATURE RESERVE FUND (RUSSIA)
}

\author{
Elena A. Starodubtseva ${ }^{1}$, Anna Ya. Grigoryevskaya², Liliya A. Lepeshkina ${ }^{2}$, Olga S. Lisova ${ }^{3}$ \\ ${ }^{1}$ Voronezh State Nature Biosphere Reserve, Russia \\ e-mail:starodbtsv@gmail.com \\ ${ }^{2}$ Voronezh State University, Russia \\ e-mail:grigaya@mail.ru,lilez1980@mail.ru \\ ${ }^{3}$ Voronezh State University of Forestry and Technologies, Russia \\ e-mail: ospopova@yandex.ru
}

Received: 06.07.2017

\begin{abstract}
The article deals with the analysis of alien species in local floras of the Voronezh region Nature Reserve Fund. The Voronezh Region is located on the border of the forest-steppe and steppe zones. 16 Model Protected Areas (PAs), having a different conservation status and a various size, have been chosen for the analysis. The article attempts to assess: a) the degree of biological contamination of PAs that protect forest-steppe and steppe ecosystems; b) features of the alien fractions of the PAs' flora of various categories. The characteristics of PAs with respect to the possibilities and conditions for the invasion of alien species of vascular plants are given. The alien fraction of the PAs' flora comprises 262 taxa: 255 species, 5 hybrids, 1 subspecies and 1 variety, referring to 178 genera and 66 families. For the typological analysis, alien species were divided into groups in accordance with the time of the invasion, the way of invasion and the naturalisation level. The average proportion of invasive species in PAs floras is $11.1 \%$ (in different local floras it varies from $4.4 \%$ to $16.8 \%$ ). When considering stable flora elements only (excluding ephemerophytes and colonophytes), then the PAs' local flora contamination ratio will make the average of $6.1 \%$ (from $3.5 \%$ to $8.9 \%$ ). The largest number of alien species is noted in the floras of state reserves and state nature sanctuaries, regional PAs are characterised by a smaller proportion of alien plants. The analysis of the ways of alien species' invasion has shown that human activity on introduction of plants makes an important contribution to the replenishment of the alien flora in protected areas: $31.7 \%$ of alien species had left the cultivation area, 15\% were deliberately planted in the PAs. Transformer plants are of the greatest coenotic significance, out of 19 such alien species 11 are xenophytes, the other 8 species are ergasiophytes. The conclusion is made about the necessity to move from the monitoring of alien species to practical work on managing the process of alien plant invasion in state reserves.
\end{abstract}

Key words: alien flora, alien plant species, invasions, Nature Reserve Fund, Protected Area

\section{Introduction}

There has been much speculation and debate on the problem of biological pollution of floras with alien plant species (= adventive species) over the last hundred years. In recent decades, a lot of efforts have been made to create databases of alien plants and compile lists of alien species of different local and regional floras, floras of particular countries and even continents. Nowadays, the world community considers the issue of biological pollution globally acute and believes that various alien plant invasions do pose a threat to biodiversity, indigenous ecosystems, resistance of biological resources and human health (McNeely et al., 2001; Vinogradova et al., 2010). This problem is especially urgent in Protected Areas (PAs), of which the main purpose is the conservation of biological diversity. In this regard, the number of publications devoted to various aspects of introduction of alien species into the PAs' floras has recently increased.
Data were synthesised for PAs of different countries and continents (Pyšek et al., 2003; Allen et al., 2009; Foxcroft et al., 2013, 2017). Many countries are actively working in the field of biological invasion management in PAs (De Poorter et al., 2007; Monaco \& Genovesi, 2014). Scientists call for improvement of management interventions, aimed at reducing the extent and magnitude of invasive plants impacts in PAs, including monitoring trends, as well as revising legislation and policies (Foxcroft et al., 2013).

In Russia, the most active studies on the issue of biological invasions have been conducted during the last two or three decades. Issues of floral pollution of various territories are discussed at all-Russian and international forums. Numerous reports on the appearance of new alien species have been published, lists of alien plants in local and regional floras are compiled. A number of generalisations on alien species in the composi- 
tion of regional floras and the analysis of the alien flora of European Russia were made (Morozova, 2003; Morozova et al., 2008). A Black Data Book of the flora of Central Russia (Vinogradova et al., 2010), as well as Black Data Books and Black Lists of individual regions of our country are published. The influence of the alien plant species on the PAs' floras in the European part of Russia has been assessed, the analysis covered 37 nature reserves (Morozova \& Tsarevskaya, 2010). The scope of published resources that consider the problem of alien species' introduction into plant communities, including PAs, is quite comprehensive. Besides, there is a necessity to estimate the level of biological pollution of the floras in PAs of different categories and of PAs' floras that belong to particular biomes (a group of ecosystems belonging to a particular natural-climatic zone) (Foxcroft et al., 2017) and the resistance of PAs' floras to biological invasions. That proves the analysis of the alien floras fractions in nature PAs representing particular biomes to be highly significant and acute.

It should be noted that currently in the Russian PAs the problem of biological invasions in PAs' ecosystems is ignored, the threat to biological diversity is underestimated, and the PAs' management in connection with alien species invasion is not discussed. A similar situation is described in detail for Ukraine (Burda, 2014).

The present work attempts to estimate the participation of alien species in local floras of the Voronezh region Nature Reserve Fund (NRF) PAs of different categories, which represent the ecosystems of steppe and forest steppe biomes. This generalisation allows us, on the one hand, to estimate the background level of biological contamination of forest-steppe ecosystems and the reference importance of Pas. On the other hand, as a result of the survey, we achieve material for analysing the characteristics of biological invasions in PAs of different categories and for developing measures to prevent the introduction of alien species into specific PAs and into specific ecosystems.

\section{Material and Methods}

The Voronezh Region Nature Reserve Fund (NRF) comprises 199 objects in total. These include 2 state nature reserves, 15 nature sanctuaries ( 2 federal-level and 13 regional-level nature sanctuaries), 1 regional-level nature park, 1 botanical garden, 179 natural monuments (177 regional and
2 local) and 1 local-level landscape garden (Negrobov, 2001; Report on environmental situation, 2015). The model PAs are the following (Fig. 1): state nature reserves (Voronezh State Nature Biosphere Reserve and Khoper Nature Reserve), state federal-level nature sanctuaries (Voronezhsky and Kamennaya Steppe), an open-air museum of architecture and archeology (Divnogorye) with conservation areas within its boundaries, and a regionallevel nature sanctuary (Voronezh uphill oakery). The regional-level natural monuments have been selected according to their type (biological, aimed at protecting nature conservation areas) and level of floristic exploration (conditioned by presence of floristic lists). The paper does not analyse arboretums and botanical gardens located in the region, as they are artificial areas intentionally created to cultivate alien trees and bushes.

The 16 selected model objects cover a total area of $843.609 \mathrm{~km}^{2}$. The data considering the time of their establishment, area, geographical and municipal location are represented in Table 1.

The analysis of the vascular plant floras of the model PAs is based on published flora lists and supplements thereto, as well as on the original material supplied by the authors of the present work who had examined the major part of the mentioned PAs. The most thoroughly studied floras are the ones of the Voronezh Nature Reserve and Khoper Nature Reserve. Correspondingly, annotated lists have been compiled (Golitsyn, 1961; Starodubtseva, 1999; Tzvelev, 1988), which are being regularly updated (Neskryabina \& Pechenyuk, 1997, 2012; Pechenyuk, 1997; Rodionova, 2000; Starodubtseva, 2007, 2011, 2012, 2013). Typical floras of nature sanctuaries have also been studied for quite a long period of time (Kamyshev, 1953, 1971; Golitsyn, 1961; Starodubtseva, 1999; Agafonov, 2004; Grigoryevskaya et al., 2004, 2008; Barabash et al., 2008; Lepeshkina, 2012). This material, together with the authors' own research, formed the basis for general floristic lists of the PAs. The data for Voronezhsky Nature Sanctuary were provided by E.A. Starodubtseva, and for Kamennaya Steppe by A.Ya. Grigoryevskaya and E.S. Gamaskova. The other PA flora studies were conducted within sporadic expeditions during 1-3 field seasons (Chernobylova et al., 2000; Agafonov, 2003; Prokhorova \& Grigoryevskaya, 2007; Grigoryevskaya \& Zelepukin, 2013). An exception is Khrenovskaya Steppe, where several generations of botanists used to work (Kamyshev, 1955, 1971; Kozhevnikova \& Chagarnaya, 1986). 


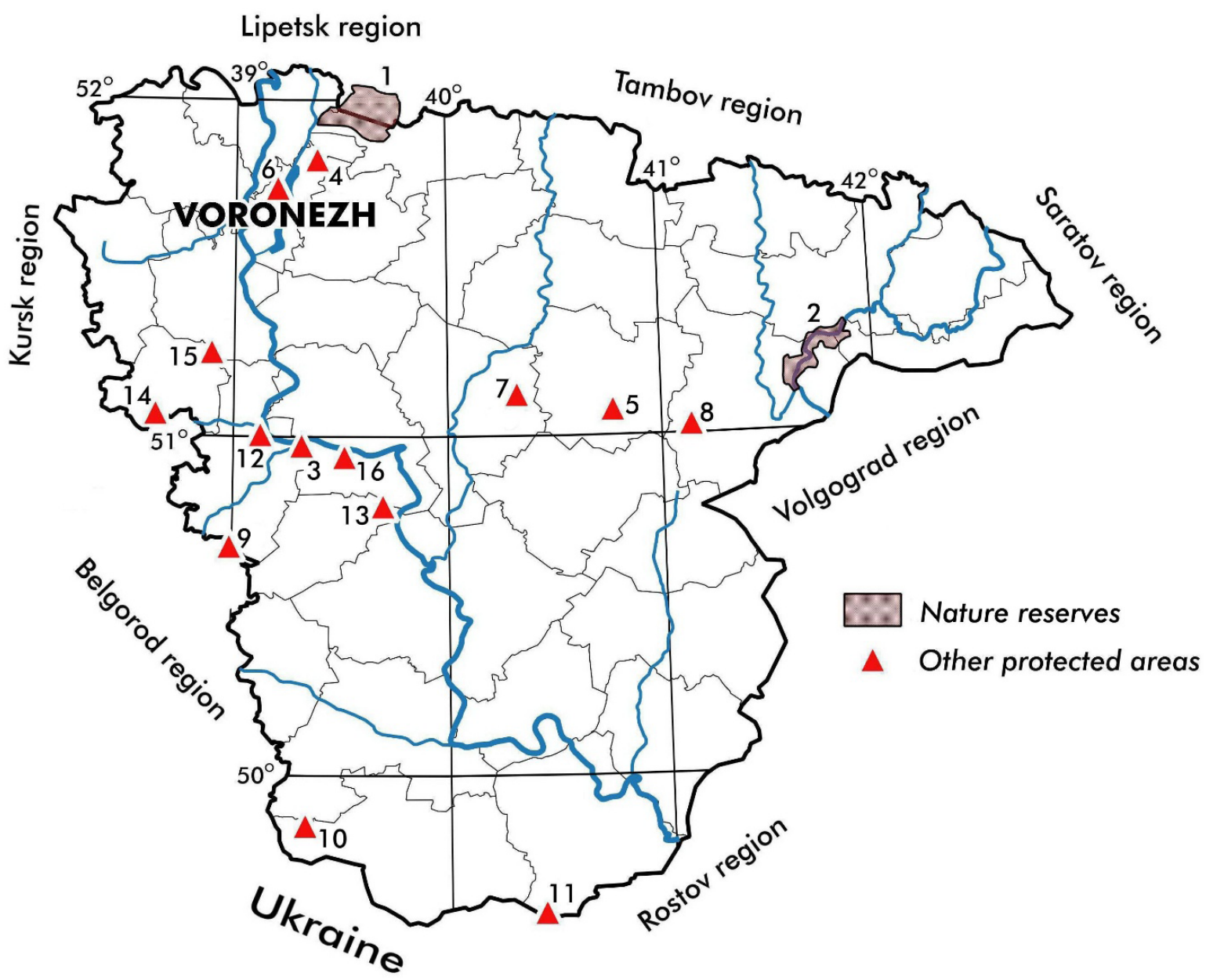

Fig. 1. Protected Areas on the map of the Voronezh region. Designations: 1 - Voronezh State Nature Biosphere Reserve; 2 - Khoper State Nature Reserve; 3 - State open-air museum of architecture and archeology «Divnogorye»; 4 - State federallevel nature sanctuary «Voronezhsky»; 5 - State federal-level nature sanctuary «Kamennaya Steppe»; 6 - Regional-level nature sanctuary «Voronezh uphill oakery»; Regional-level natural monuments: 7 - Khrenovskaya Steppe; 8 - Krasnyanskaya Steppe; 9 - Steppe Hillslopes by Vladimirovka settlement; 10 - Volokonovskaya Steppe; 11 - Khripunskaya Steppe; 12 Melovaya Sosna; 13 - Golik; 14 - Maydan; 15 - Krutzy; 16 - Kreyda na Zapadne.

To compile the alien species database, plants were registered which grow directly in the PA (by contrast, species noted as present in the buffer zones around reserves were not included). Besides, we took into account the fact that some PAs include cordons, vegetable gardens, ordinary gardens, arboretums, or field-protecting shelter belts, as in the case of Kamennaya Steppe nature sanctuary. It is worth noticing that alien plants cultivated or growing wild in these artificial territories have not been included on the list of PAs' alien flora. The present article analyses data on the alien flora of the Vorone$\mathrm{zh}$ region PAs available before 1 January 2015.

During the research, scientists followed such traditional methods of flora analysis as taxonomic, typological, comparative and statistical. All the information collected was processed in a Microsoft Excel matrix table. A typological analysis has been carried out according to classification categories of alien species outlined in «Adventive flora of Voronezh region»
(Grigoryevskaya et al., 2004). The groups of alien species were defined according to their invasion time, i.e. the time of their appearance in the region. Thus, archaeophytes appeared before the end of the 17th - at the beginning of the 18th century, then follow neophytes that appeared between the beginning of the 18th and the first decade of the 20th century, and euneophytes (after the first decade of the $20^{\text {th }}$ century). There are also several groups defined in accordance with the way of invasion: xenophytes, i.e. species that appeared in the region spontaneously; ergasiolypophytes, i.e. alien plants specially planted by man into the natural environment or natural-artificial areas; ergasiophygophytes, i.e. alien species that left its places of cultivation. The terms «ergasiophygophytes», «ergasiolypophytes» and «xenophytes» were proposed by Rikli, (1903), Thellung (1918-1919), Holub \& Jirasek (1967); these terms are widely used in publications devoted to the study of alien species (e.g., Ponert, 1977; Grigoryevskaya et al., 2004). 
Table 1. The characteristics of the model Protected Areas belonging to the Voronezh region Nature Reserve Fund

\begin{tabular}{|c|c|c|c|c|c|}
\hline \multirow{2}{*}{ Protected Area } & \multicolumn{2}{|c|}{$\begin{array}{l}\text { Geographic } \\
\text { coordinates }\end{array}$} & \multirow{2}{*}{ Municipal district } & \multirow{2}{*}{ Area, $\mathrm{km}^{2}$} & \multirow{2}{*}{$\begin{array}{c}\text { Year of } \\
\text { establishment }\end{array}$} \\
\hline & $\begin{array}{l}\text { North } \\
\text { latitude }\end{array}$ & $\begin{array}{c}\text { East } \\
\text { longitude }\end{array}$ & & & \\
\hline \multicolumn{6}{|c|}{ State nature reserves } \\
\hline $\begin{array}{l}\text { Voronezh State Nature } \\
\text { Biosphere Reserve }\end{array}$ & $\begin{array}{c}51^{\circ} 52^{\prime}- \\
52^{\circ} 02^{\prime}\end{array}$ & $\begin{array}{c}39^{\circ} 21^{\prime}- \\
39^{\circ} 47^{\prime}\end{array}$ & $\begin{array}{l}\text { Verkhnekhavsky District, Voronezh } \\
\text { Region } \\
\text { Usmansky District, Lipetsk Region }\end{array}$ & 310.53 & $\begin{array}{c}1923 \text { (contemporary } \\
\text { boundaries since } \\
1935)\end{array}$ \\
\hline Khoper Nature Reserve & $50^{\circ} 42^{\prime}$ & $42^{\circ} 00^{\prime}$ & $\begin{array}{c}\text { Gribanovsky District, Novokhopersky } \\
\text { District, } \\
\text { Povorinsky District }\end{array}$ & 161.78 & 1935 \\
\hline \multicolumn{6}{|c|}{ State open-air museum of architecture and archeology } \\
\hline Divnogorye & $50^{\circ} 58^{\prime}$ & $39^{\circ} 19^{\prime}$ & Liskinsky District & 11.00 & 1991 \\
\hline \multicolumn{6}{|c|}{ State federal-level nature sanctuaries } \\
\hline Voronezhsky & $51^{\circ} 48^{\prime}$ & $39^{\circ} 24^{\prime}$ & $\begin{array}{c}\text { Verkhnekhavsky District, } \\
\text { Novousmansky District, } \\
\text { Municipal district of Voronezh }\end{array}$ & 229.997 & 1958 \\
\hline Kamennaya Steppe & $51^{\circ} 02^{\prime}$ & $40^{\circ} 45^{\prime}$ & Talovsky District & 52.32 & 1996 \\
\hline \multicolumn{6}{|c|}{ Regional-level nature sanctuary } \\
\hline Voronezh uphill oakery & $51^{\circ} 43^{\prime}$ & $39^{\circ} 13^{\prime}$ & $\begin{array}{c}\text { Ramonsky District, } \\
\text { Municipal district of Voronezh }\end{array}$ & 70.98 & 2013 \\
\hline \multicolumn{6}{|c|}{ Regional-level natural monuments } \\
\hline Khrenovskaya Steppe & $51^{\circ} 06.5^{\prime}$ & $40^{\circ} 19.5^{\prime}$ & Bobrovsky District & 0.80 & 1998 \\
\hline Krasnyanskaya Steppe & $51^{\circ} 02^{\prime}$ & $41^{\circ} 14^{\prime}$ & NovoKhopersky District & 1.00 & 1969 \\
\hline $\begin{array}{l}\text { Volokonovskaya Steppe } \\
\text { (Kruglenkoe area) }\end{array}$ & $49^{\circ} 51.5^{\prime}$ & $39^{\circ} 21.5^{\prime}$ & Kantemirovsky District & 0.25 & 1969 \\
\hline Khripunskaya Steppe & $49^{\circ} 35.5^{\prime}$ & $40^{\circ} 27^{\prime}$ & Bogucharsky District & 0.13 & 1969 \\
\hline $\begin{array}{l}\text { Steppe Hillslopes by } \\
\text { Vladimirovka settlement }\end{array}$ & $50^{\circ} 39.5^{\prime}$ & $39^{\circ} 00.5^{\prime}$ & Ostrogozhsky District & 0.06 & 1969 \\
\hline Melovaya Sosna (or Mordva) & $51^{\circ} 01.5^{\prime}$ & $39^{\circ} 05^{\prime}$ & Ostrogozhsky District & 0.012 & 1969 \\
\hline Golik & $50^{\circ} 46^{\prime}$ & $39^{\circ} 46.5^{\prime}$ & Kamensky District & 0.15 & 1980 \\
\hline Maydan & $51^{\circ} 02.5^{\prime}$ & $38^{\circ} 40.5^{\prime}$ & Repyovsky District & 0.60 & 1969 \\
\hline Krutzy & $51^{\circ} 16^{\prime}$ & $38^{\circ} 51^{\prime}$ & Repyovsky District & 2.00 & 1969 \\
\hline Kreyda na Zapadne & $50^{\circ} 55.5^{\prime}$ & $39^{\circ} 30^{\prime}$ & Liskinsky District & 2.00 & 1969 \\
\hline
\end{tabular}

In terms of naturalisation level the alien species were divided into four groups:

1) ephemerophytes - non-naturalised plants, each appearance of these species is associated with a new propagule introduction. In the classification of the alien species' invasive status (Richardson et al., 2000), this group corresponds to «casual alien plants»;

2) colonophytes - species that are growing in the invaded area for quite a long period, they are reproducing, but not spreading further. This group corresponds to «naturalised plants» (Richardson et al., 2000);

3 ) epecophytes - species that are naturalised and spreading in plant communities in secondary habitats;

4) agriophytes - species that are naturalised and spreading in natural and close-to-natural plant communities.
The third and fourth group of alien species correspond to «invasive plants» and «transformers» by Richardson et al. (2000). We do not consider in detail the issues of alien species terminology and classification in our article, since a large number of publications have been devoted to this topic (see Pyšek et al. (2002a), Grigoryevskaya et al. (2004), Vinogradova et al. (2010) for a discussion on terminology).

In general, the nomenclature follows «Flora of the European part of the USSR» (1974-1989), «Flora of Eastern Europe» (Tzvelev, 1996, 2001, 2004), «Flora of Middle belt of the European part of Russia» (Maevskiy, 2014), except for a few species that are absent in these publications. The total list of species and their distribution in PAs are presented in the Appendix. The Jaccard similarity coefficient was used in order to compare the alien floras of the Central Russian forest-steppe NRF objects. 


\section{Results and Discussion}

Representation of the model NRF objects in the Voronezh region with relation to ecosystems and floristic diversity. While analysing the biodiversity of the Voronezh region and the processes of alien plant introduction into the ecosystems, it should be noted that the south boundary of the forest steppe zone runs directly through the territory of the Voronezh region. In fact, the way this line is drawn varies in the botanical and physiographic zoning of the territory (as shown in Table 2).

According to the phytogeographical zoning there are two provinces in the Voronezh region: 1) The Eastern Europe forest steppe province, represented by the Central Russian (Upper Don) subprovince, and 2) The Black sea steppe province, represented by the Middle-Don subprov- ince. The boundary between forest steppe and steppe runs through Ostrogozhsk and Liski, then further following the $51^{\circ}$ latitude. The zonal ecosystems of forest steppe biome include oak forests, forb-fescue-feather grass steppes and aspen bushes; pine forests occupying the sandy left bank fluvial terraces represent the azonal type of ecosystems. The steppe biome is represented by forb-fescue grass steppes.

The physiographic zoning «moves» the boundary of forest steppe and steppe zones to the very south of the Voronezh region (to the south of $50^{\circ} \mathrm{N}$ ), marking out two forest steppe provinces (in the Oka-Don Lowland and in the Central Russian Upland) and one steppe province (in the Central Russian Upland) in the territory of the region (Fedotov, 2013).

Table 2. The model Protected Areas' correlation with the units of phytogeographical and physiographic zoning of the Voronezh region

\begin{tabular}{|c|c|c|c|c|c|}
\hline \multicolumn{2}{|c|}{$\begin{array}{c}\text { Phytogeographical zoning } \\
(1-\text { provinces, subprovinces, } 2-\text { districts })\end{array}$} & \multirow[t]{2}{*}{ Protected Areas } & \multicolumn{3}{|c|}{$\begin{array}{c}\text { Physiographic zoning } \\
(1-\text { natural zones, } 2 \text { - provinces, } 3 \text { - areas })\end{array}$} \\
\hline 1 & 2 & & 1 & 2 & 3 \\
\hline \multirow{9}{*}{ 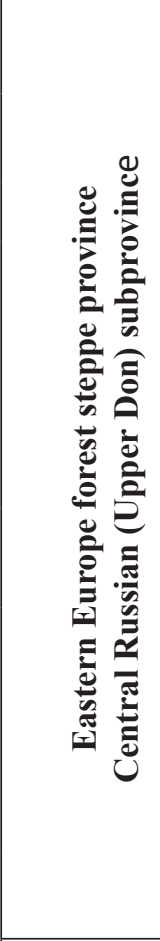 } & $\begin{array}{l}\text { Usmanskiy district of } \\
\text { greenmoss pine and sedge } \\
\text { oak forests }\end{array}$ & $\begin{array}{c}\begin{array}{c}\text { Voronezh State Nature } \\
\text { Biosphere Reserve }\end{array} \\
\text { Voronezhsky Nature } \\
\text { Sanctuary } \\
\end{array}$ & \multirow{13}{*}{ 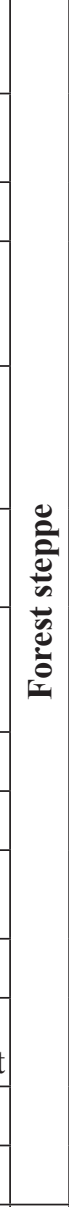 } & \multirow{4}{*}{$\begin{array}{c}\text { Forest steppe province } \\
\text { of Oka-Don Lowland }\end{array}$} & \multirow[t]{2}{*}{$\begin{array}{c}\text { I. Left bank valley terrace } \\
\text { area of typical forest } \\
\text { steppe }\end{array}$} \\
\hline & \multirow{5}{*}{$\begin{array}{l}\text { Anninskiy district of } \\
\text { goutweed oak forests, } \\
\text { aspen bushes and forb- } \\
\text { fescue-feather grass } \\
\text { steppes }\end{array}$} & Voronezh uphill oakery & & & \\
\hline & & Khrenovskaya Steppe & & & $\begin{array}{l}\text { III. South Bityug-Khoper } \\
\text { area of south forest steppe }\end{array}$ \\
\hline & & Khoper Nature Reserve & & & $\begin{array}{l}\text { IV. Middle Khoper valley } \\
\text { area of south forest steppe }\end{array}$ \\
\hline & & Kamennaya Steppe & & $\begin{array}{c}\text { Boundary between the } \\
\text { provinces }\end{array}$ & $\begin{array}{l}\text { Boundary between areas } \\
\text { III and VII }\end{array}$ \\
\hline & & Krasnyanskaya Steppe & & \multirow{8}{*}{$\begin{array}{c}\text { Forest steppe province } \\
\text { of the Central Russian } \\
\text { Upland }\end{array}$} & $\begin{array}{l}\text { VII. Kalach ravine-and- } \\
\text { gully area of south forest } \\
\text { steppe }\end{array}$ \\
\hline & \multirow{3}{*}{$\begin{array}{l}\text { Hokholsky district of oak } \\
\text { forests and forb-feather } \\
\text { grass steppes }\end{array}$} & Maydan & & & \multirow{3}{*}{$\begin{array}{l}\text { V. Don-adjacent chalky } \\
\text { area of typical forest } \\
\text { steppe }\end{array}$} \\
\hline & & Krutzy & & & \\
\hline & & $\begin{array}{l}\text { Melovaya sosna (or } \\
\text { Mordva) }\end{array}$ & & & \\
\hline \multirow{6}{*}{ 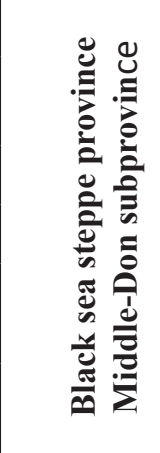 } & \multirow{5}{*}{$\begin{array}{l}\text { Rossoshansky district } \\
\text { of fescue-feather grass } \\
\text { steppes }\end{array}$} & Divnogorye & & & \multirow{4}{*}{$\begin{array}{l}\text { VI. Kalitvinsky billowy- } \\
\text { and-gully area of south } \\
\text { forest steppe }\end{array}$} \\
\hline & & \begin{tabular}{|c|} 
Hillslopes by \\
Vladimirovka settlement
\end{tabular} & & & \\
\hline & & Kreyda na Zapadne & & & \\
\hline & & Golik & & & \\
\hline & & $\begin{array}{c}\text { Volokonovskaya Steppe } \\
\text { (Kruglenkoye area) }\end{array}$ & \multirow{2}{*}{$\frac{\grave{2}}{\frac{\mathscr{2}}{\omega}}$} & \multirow{2}{*}{$\begin{array}{c}\text { Steppe province of } \\
\text { the Central Russian } \\
\text { Upland }\end{array}$} & \multirow{2}{*}{$\begin{array}{l}\text { VIII. Bogucharsky left } \\
\text { bank billowy-and-gully } \\
\text { steppe area }\end{array}$} \\
\hline & $\begin{array}{l}\text { Bogucharsky district of } \\
\text { forb-fescue grass steppes }\end{array}$ & Khripunskaya steppe & & & \\
\hline
\end{tabular}


Within the landscape zoning these territories belong to the Central Russian chalky and Oka-Don sandy-argillaceous landscape-ecological areas; according to the soil-geographical zoning they belong to the province of moderately freezing black soils of forest steppe and to the province of grey forest steppe soils (Akhtyrtsev \& Akhtyrtsev, 1993).

Representing most of the physiographic regions of the Voronezh region, the model PAs reflect the diversity of zonal and azonal landscapes of typical and south forest steppe, including native and derived plant communities with different regimes of natural resource management and reflecting the diversity of regional flora of vascular plants by over $90 \%$ (see Table 3 ).

Within the floristic zoning the explored territory belongs to the Holarctic Kingdom, the Boreal Subkingdom, the Circumboreal floristic region, the Eastern European Province (Takhtajan, 1978). When considering the systematic structure of the regions' flora of the Central Black Earth Region Bukhalo (1989) chose the Central Black Earth subprovince as a subdominant unit within the floristic province, and as for the territory of the Voronezh region, he included it in the South Central Black Earth floristic region.

Nature Reserve Fund characteristics: facilities and conditions for invasion of alien vascular plant species. The NRF of the Voronezh region is located in the region of intensive economic use. According to the 2015 Rosstat (Russian Federal State Statistics Service) report, the regional population density is 44.6 people per $\mathrm{km}^{2}$, with the urban population accounting for $66.9 \%$. Wooded lands in the region account for $8.8 \%$; cultivated lands account for $55.6 \%$ in the general structure of land resources, urban land occupies $8.9 \%$ of the total area of the region (Report on environmental situation, 2015). Under such conditions, all specially PAs (PAs account for $3.17 \%$ of the land resources) can be compared to so-called "islands" isolated amid anthropogenic landscapes.

Table 3. Representation of forest steppe biome ecosystems in the model Protected Areas and their floristic diversity

\begin{tabular}{|c|c|c|c|}
\hline Protected Areas & Characteristics of protected ecosystems & $\begin{array}{l}\text { Total number of } \\
\text { vascular plants }\end{array}$ & $\begin{array}{l}\text { Number and } \\
\text { proportion of } \\
\text { alien species }\end{array}$ \\
\hline \multicolumn{4}{|c|}{ State nature reserves } \\
\hline $\begin{array}{l}\text { Voronezh Biosphere } \\
\text { Reserve }\end{array}$ & $\begin{array}{l}\text { Forest ecosystems: pine forests, oak forests, aspen forests, } \\
\text { sticky alder forests; swamps, meadows }\end{array}$ & 1036 & $174(16.8 \%)$ \\
\hline Khoper Reserve & Floodplain ecosystems, broad-leaf forests, steppe areas, meadows & 1075 & $121(11.3 \%)$ \\
\hline \multicolumn{4}{|c|}{ State open air museum of architecture and archeology } \\
\hline Divnogorye & Petrophytous steppes, «lowered alpine plants» & 652 & $54(8.3 \%)$ \\
\hline \multicolumn{4}{|c|}{ Federal level state nature sanctuaries } \\
\hline Voronezhsky & $\begin{array}{l}\text { Forest ecosystems: pine forests, oak forests, aspen forests, } \\
\text { sticky alder forests; swamps, meadows }\end{array}$ & 744 & $103(13.8 \%)$ \\
\hline Kamennaya Steppe & Forest-agroecosystems, steppe stows, abandoned fields, ponds & 971 & $111(11.4 \%)$ \\
\hline \multicolumn{4}{|c|}{ Regional-level nature sanctuaries } \\
\hline Voronezh uphill oakery & Forest ecosystems (mixed forests) & 585 & $59(10.1 \%)$ \\
\hline \multicolumn{4}{|c|}{ Regional-level nature monuments } \\
\hline Khrenovskaya Steppe & Forest steppe complex & 487 & $40(8.2 \%)$ \\
\hline Krasnyanskaya Steppe & Feather-grass steppes & 480 & $21(4.4 \%)$ \\
\hline $\begin{array}{l}\text { Hillslopes by } \\
\text { Vladimirovka settlement }\end{array}$ & Steppe ecosystems & 403 & $21(5.2 \%)$ \\
\hline Volokonovskaya Steppe & $\begin{array}{l}\text { Suffrutescent communities, fragments of feather-grass (Stipa } \\
\text { capillata) steppes on chalky outcrops }\end{array}$ & 528 & $31(5.9 \%)$ \\
\hline Khripunskaya Steppe & Fescue-feather grass steppes & 328 & $16(4.9 \%)$ \\
\hline $\begin{array}{l}\text { Melovaya Sosna (or } \\
\text { Mordva) }\end{array}$ & Pine forest tract on chalky outcrops, meadow steppe slopes & 224 & $13(5.8 \%)$ \\
\hline Golik & «Lowered alpine plants», thyme plants, hyssop plants & 331 & $17(5.1 \%)$ \\
\hline Maydan & Feather-grass and petrophytic-calcareous steppes & 149 & $11(7.4 \%)$ \\
\hline Krutzy & Petrophytic-calcareous steppe & 173 & $10(5.8 \%)$ \\
\hline Kreyda na Zapadne & Calcareous steppes & 122 & $12(9.8 \%)$ \\
\hline
\end{tabular}


The Nature Reserve Fund of the Voronezh region includes PAs of the federal and regional levels with different regimes of natural resource management: from total removal from the anthropogenic activities (nature reserves) to limited and controlled of economic activities (nature sanctuaries and natural monuments). Today's State Nature Reserve Activity Regulations prohibit anthropogenic activities in these territories, but the existing Voronezh region reserves were initially founded in areas that had already suffered from a considerable human impact. Primarily, these areas were set up as preserves aimed at protecting certain animal species from being hunted, and for a long period they had been feeling the anthropogenic impact (approximately until the early 1980s), such as purposive introduction of alien species of plants and animals, as well as the conduct of biotechnical, forestry and other activities. Such sources and ways of species distribution as roads and railways, populated places or agricultural fields, located within reserves or nearby provide favourable conditions for alien species invasion. From this point of view, the level of protection against alien species in the reserves does not differ from the one in nature sanctuaries or natural monuments. Furthermore, the conduct of economic activities during the preservation period eliminates the difference between state nature reserves (with longer terms of preservation regime) and other PAs (Voronezh Nature Reserve was established in 1923, Khoper Nature Reserve - in 1935, most natural monuments - in 1969). The differences in the PA categories that are meaningful for biological invasion analysis include the following:

a) size of the territory: nature reserves normally occupy an area from $160 \mathrm{~km}^{2}$ to $310 \mathrm{~km}^{2}$, nature sanctuaries - from $50 \mathrm{~km}^{2}$ to $230 \mathrm{~km}^{2}$, natural monuments - from $0.012 \mathrm{~km}^{2}$ to $2.000 \mathrm{~km}^{2}$ (see Table 1);

b) visiting regulations: reserves do not allow free access and recreation whereas nature sanctuaries and natural monuments do.

Special mentioning should be made of federallevel nature sanctuaries. The Voronezhsky Nature Sanctuary was primarily established as a hunting reserve; geographically it is located in the south of Usman Pine Forest and it belongs partially to the administrative boundaries of Voronezh Urban Okrug. The River Usman, which flows through the territory of the nature sanctuary, and a small part of the River Voronezh, are traditional relaxation areas for the people from Voronezh. There are children's health camps and recreation camps on the banks of the River Usman. There are also populated places within the boundaries of the nature sanctuary. Generally, this area is characterised by a long history of natural resource management; at present more than one hundred tracts of land within the boundaries of the nature sanctuary are rented out for forestry activities, agriculture, recreation and other activities.

The Kamennaya Steppe Nature Sanctuary enjoys a special status. At the end of the 19th century, a unique experiment of steppe farming protection from storms and droughts was set up in this territory. In one of the most arid regions of Central Russia, the development of optimised south forest-steppe agrolandscape began under the supervision of V.V. Dokuchaev. As a result, a system of field-protecting shelter belts and ponds was developed; two arboretums were founded, in 1927 and 1929 correspondingly, and the introduction of tree and shrub species began; different methods of steppe vegetation conservation (e.g. haying, total conservation) were applied on steppe tracts and abandoned fields. The attempts to establish PAs in Kamennaya Steppe had been made since the 1930s, when a preservation regime for some stows was introduced, but it was only in 1996 when a federallevel nature sanctuary was founded. The sanctuary is complex targeted; it has agroecological specialisation and is designed for preservation and reconstruction of environmentally protecting anthropogenic forestagricultural landscapes, as well as for preservation of endangered animal species and their habitat. The Kamennaya Steppe has become one of the main centres of tree and shrub species' introduction in the Central Black Earth region. It was here where plans of fieldprotecting shelter belts' creation were developed, the species composition of these woodlands was selected, with more than two hundred invasive tree and shrub species tested for these purposes.

In the 1940-1950s Stalin's plan for "transformation of nature" was carried out not only by specialised organisations and forestries but also by state reserves of the Voronezh region, delivering seed and planting material of both local trees and shrubs and alien species, grown in nurseries to create field-protecting shelter belts along the roads, fields and gullies. According to Mashkin (1952), 430 introduced species of trees and shrubs were grown in the Voronezh region in the 60s of the last century; the data by Egorov et al. (1967) showed that alien taxa make up 20-75\% of the dendroflora of shelter belts. The effectiveness and productivity of shelter belts were increased by the introduction of alien fast-growing tree species, fruit and nut crops, such as Acer negundo L., Fraxinus lanceolata Borkh., Amelanchier spicata (Lam.) K. Koch, Juglans cinerea L. On medium- and deephumified sandy soil woodlands such species as Larix 
sibirica Ledeb., Cotinus coggygria Scop., Lonicera tatarica L., Robinia pseudoacacia L., Sambucus racemosa L. had been established. Protective afforestation altered the image of forest steppe fundamentally and enriched this biome by a number of alien species. According to the latest research, more than 40 introduced tree and shrub species have become invasive on the territory of the Central Russian forest steppe (Lepeshkina et al., 2014).

The analysis of the alien flora fraction of the Nature Reserve Fund. It was revealed that the model PAs' flora consisted of 262 alien taxa: 255 species, 5 hybrids (Aster $\times$ salignum Willd., Fragaria $\times$ ananassa (Weston) Duch., Medicago $\times$ varia T. Martyn, Populus $\times$ berolinensis (C. Koch) Dipp., Tulipa $\times$ hybrida hort.), 1 subspecies (Larix decidua Mill. subsp. polonica (Racib. ex Wóycicki) Domin), 1 variety (Phalaroides arundinacea var. picta Tzvelev), which refer to 178 genera and 66 families. In the quantitative analysis of the PAs' alien flora, hybrids, the subspecies and the variety were taken into account on a par with species. The gymnosperms are represented by two families; among the angiosperms 9 families represent the class of Monocotyledons, and 55 belong to the class of Dicotyledons. The number of alien species in the flora of the Nature Reserve Fund of the Voronezh region makes up $58 \%$ of all alien flora of the region (Grigoryevskaya et al., 2004). 15 Families (22\%) out of the 66 families of the alien flora are completely alien. These are: Amaranthaceae, Anacardiaceae, Araliaceae, Cucurbitaceae, Elaeagnaceae, Hippocastanaceae, Hydrangeaceae, Hydrophyllaceae, Juglandaceae, Oxalidaceae, Portulacacae, Rutaceae, Schisandraceae, Vitaceae, Zigophyllaceae.

The first six leading families in the alien flora of Voronezh PAs correspond to the six leading families of alien flora of European Russia (Morozova et al., 2008), as shown in Table 4. Seven leading families are similar to the leading families of the alien flora of the Voronezh region. They contain $51 \%$ of all alien species of the Nature Reserve Fund. It is also important to mention that the main difference between the flora of the three leading groups of PAs and the flora of the European part of Russia is that PAs contain the family Rosaceae. This family mainly includes tree and shrub plants that were deliberately grown on the PAs (ergasiolypophytes) or that have left the cultivation zone (ergasiophygophytes).

Table 4. Taxonomic spectra of alien flora of model Protected Areas in the Voronezh region compared to alien fractions of European Russia and the Voronezh region floras

\begin{tabular}{|c|c|c|c|c|c|c|c|c|c|c|c|c|c|}
\hline & The number & & & & & & & & & & & & \\
\hline & of species & 1 & 2 & 3 & 4 & 5 & 6 & 7 & 8 & 9 & 10 & 11 & 12 \\
\hline European Russia $^{1}$ & 1610 & As & Po & $\mathrm{Br}$ & Ro & $\mathrm{Fa}$ & $\mathrm{Ch}$ & $\mathrm{La}$ & Ap & Car & $\mathrm{Pg}$ & Sc & \\
\hline Voronezh Region $^{2}$ & 435 & Po & As & Ro & $\mathrm{Fa}$ & $\mathrm{Br}$ & $\mathrm{Ch}$ & $\mathrm{Pi}$ & Ap & $\mathrm{La}$ & $\mathrm{Ma}$ & & \\
\hline All PAs & 262 & $\begin{array}{l}\text { As } \\
33^{3}\end{array}$ & $\begin{array}{l}\text { Po } \\
30\end{array}$ & $\begin{array}{c}\text { Ro } \\
21\end{array}$ & $\begin{array}{l}\mathbf{B r} \\
15\end{array}$ & \begin{tabular}{c|} 
Ch \\
13
\end{tabular} & $\begin{array}{l}\mathbf{F a} \\
12\end{array}$ & $\begin{array}{l}\mathbf{P i} \\
10\end{array}$ & $\begin{array}{c}\mathbf{S a} \\
8\end{array}$ & $\begin{array}{c}\text { Car } \\
7\end{array}$ & $\begin{array}{c}\text { So }= \\
6\end{array}$ & $\begin{array}{c}\text { Cap } \\
6\end{array}$ & $\underset{6}{\mathrm{Am}}$ \\
\hline Voronezh Nature Reserve & 174 & $\begin{array}{l}\text { As } \\
25\end{array}$ & $\begin{array}{l}\text { Po } \\
15\end{array}$ & $\begin{array}{l}\text { Ro } \\
11 \\
\end{array}$ & $\begin{array}{c}\mathrm{Br}= \\
9 \\
\end{array}$ & $\begin{array}{c}\mathrm{Pi} \\
9\end{array}$ & $\begin{array}{c}\mathrm{Fa} \\
8\end{array}$ & $\begin{array}{c}\mathrm{Sa} \\
7\end{array}$ & $\begin{array}{c}\text { Car }= \\
6\end{array}$ & $\begin{array}{c}\text { Ch } \\
6 \\
\end{array}$ & $\begin{array}{c}\text { So } \\
5\end{array}$ & $\begin{array}{c}\mathrm{La}= \\
4\end{array}$ & $\begin{array}{c}\mathrm{Ma} \\
4\end{array}$ \\
\hline $\begin{array}{l}\text { Voronezhsky Nature } \\
\text { Sanctuary }\end{array}$ & 103 & $\begin{array}{l}\text { Po } \\
22 \\
\end{array}$ & $\begin{array}{l}\text { As } \\
15\end{array}$ & $\begin{array}{c}\text { Ro } \\
8\end{array}$ & $\begin{array}{c}\mathrm{Fa} \\
6 \\
\end{array}$ & $\begin{array}{c}\mathrm{Br} \\
4 \\
\end{array}$ & Car & & & & & & \\
\hline Voronezh uphill oakery & 59 & $\begin{array}{l}\mathrm{Po} \\
16\end{array}$ & $\begin{array}{c}\text { As } \\
9\end{array}$ & $\begin{array}{c}\mathrm{Br} \\
4\end{array}$ & Car, & Cap, & Ac 3 & & & & & & \\
\hline $\begin{array}{l}\text { Kamennaya Steppe Nature } \\
\text { Sanctuary }\end{array}$ & 111 & $\begin{array}{l}\text { Ro } \\
14 \\
\end{array}$ & $\begin{array}{l}\text { As } \\
13 \\
\end{array}$ & $\begin{array}{c}\text { Po } \\
9\end{array}$ & $\begin{array}{c}\mathrm{Br}= \\
7 \\
\end{array}$ & $\begin{array}{c}\mathrm{Ch} \\
7 \\
\end{array}$ & $\begin{array}{c}\text { Car } \\
6 \\
\end{array}$ & $\begin{array}{c}\mathrm{Fa}= \\
5\end{array}$ & $\begin{array}{c}\text { Cap } \\
5\end{array}$ & $\begin{array}{r}\mathrm{Pi}, \\
4 \\
\end{array}$ & & Gr, & $\begin{array}{l}\mathrm{Sa}, \mathrm{Am} \\
\mathrm{Ac}(3)\end{array}$ \\
\hline Khoper Nature Reserve & 120 & $\begin{array}{l}\text { Po } \\
20 \\
\end{array}$ & \begin{tabular}{l|} 
As \\
16 \\
\end{tabular} & $\begin{array}{c}\text { Ch } \\
9 \\
\end{array}$ & $\begin{array}{c}\mathrm{Fa} \\
7 \\
\end{array}$ & $\begin{array}{c}\mathrm{Br} \\
6 \\
\end{array}$ & $\begin{array}{c}\mathrm{Am} \\
5\end{array}$ & $\begin{array}{c}\mathrm{Ro}= \\
4\end{array}$ & $\begin{array}{c}\text { On } \\
4\end{array}$ & & $\begin{array}{c}\mathrm{Cu}, \mathrm{La} \\
3\end{array}$ & $a=$ & \begin{tabular}{|c|} 
Cap, Pi, Gr \\
3 \\
\end{tabular} \\
\hline Divnogorye & 54 & $\begin{array}{l}\text { As } \\
12 \\
\end{array}$ & $\begin{array}{l}\text { Po } \\
10 \\
\end{array}$ & $\begin{array}{c}\mathrm{Br} \\
4 \\
\end{array}$ & $\begin{array}{c}\mathrm{Ch} \\
3 \\
\end{array}$ & - & & & & & & & \\
\hline All natural monuments $(\mathrm{NM})^{4}$ & 54 & $\begin{array}{l}\text { As } \\
15\end{array}$ & $\begin{array}{l}\text { Po } \\
11 \\
\end{array}$ & $\begin{array}{c}\mathrm{Ch} \\
5\end{array}$ & $\begin{array}{c}\mathrm{Br} \\
4 \\
\end{array}$ & Car & & & & & & & \\
\hline Khrenovskaya Steppe NM & 40 & $\begin{array}{l}\text { As } \\
12 \\
\end{array}$ & $\begin{array}{c}\text { Po } \\
7\end{array}$ & $\begin{array}{c}\mathrm{Br} \\
4\end{array}$ & $\begin{array}{c}\mathrm{Ch} \\
3\end{array}$ & & & & & & & & \\
\hline $\begin{array}{l}{ }^{1}-\text { according to Morozova et a } \\
2-\text { according to Grigoryevskay } \\
3 \text { - the number of species; }{ }^{4}-\mathrm{d} \\
\text { of the general list of alien spec } \\
\text { most numerous. NM - natural } \\
=- \text { the family in this column al } \\
\text { of genera in the first one is lar } \\
\text { ceae, Cap - Caprifoliaceae, Ca } \\
\text { sulariaceae, La - Lamiaceae, I } \\
\text { lygonaceae, Po-Poaceae, Ro }\end{array}$ & $\begin{array}{l}\text { l. (2008). } \\
\text { a et al. (2004) } \\
\text { le to a small n } \\
\text { ies. Additiona } \\
\text { monument. } \\
\text { hd the family i } \\
\text { ger; Ac-Acer } \\
\text { i-Caryophy } \\
\text { - - Lemnaced } \\
\text { - Rosaceae, }\end{array}$ & $n$ & ei & bc & $\begin{array}{l}\text { eci } \\
\text { vas } \\
\text { ara }\end{array}$ & $\mathrm{mnn}$ & $\begin{array}{l}\text { ont } \\
e, A\end{array}$ & $\begin{array}{l}\text { ope } \\
\text { en } \\
\text { the } \\
A p \\
F a \\
\mathrm{Or}\end{array}$ & $\begin{array}{l}\text { ural } \\
\text { a list } \\
\text { lal nı } \\
\text { eae, } \\
\text { eae, }\end{array}$ & $\begin{array}{c}\text { ber } \\
- \\
-\end{array}$ & $\begin{array}{l}\text { t an a } \\
\text { ovska }\end{array}$ & $\begin{array}{l}\text { analysis } \\
\text { caya Ste } \\
\text { es, but } t \\
\text { ae, } \mathrm{Br}- \\
\text { taceae, }\end{array}$ & $\begin{array}{l}\text { is was made } \\
\text { eppe, as the } \\
\text { the number } \\
\text { - Brassica- } \\
\text { Gr - Gros- } \\
\text { ae, Pg-Po- }\end{array}$ \\
\hline
\end{tabular}


The next three leading families are Brassicaceae, Chenopodiaceae, Fabaceae, which are indicative of xerophilous properties of the flora. The peculiarity of the regional alien flora is the presence of Pinaceae in the spectrum of leading families. This is the result of introduction of many coniferous species, including their introduction into nature reserve territories. The alien flora of Voronezh PAs differs from the European and regional flora in the absence of Apiaceae and a higher proportion of Salicaceae.

As a result of the analysis of the leading families in the local floras of particular PAs the following peculiarities were witnessed:

In most PAs that perform forest ecosystem protection, the Rosaceae are the leading family. Kamennaya Steppe Nature Sanctuary has the highest rate of Rosaceae taxa. A high proportion of the Pinaceae is exclusively due to the contribution of reserves (Voronezh Nature Reserve mainly, and Khoper Nature Reserve to a lesser extent), in the territories of which various species of coniferous tree used to be cultivated. Within the range of the leading families of protected steppe ecosystems, the Chenopodiace$a e$ is in the first four. In Kamennaya Steppe Nature Sanctuary, on the territory of which there are steppe plots and deposits, this family ranks fifth. It is interesting that in the Khoper Reserve, the Chenopodiaceae take the third position in the range of the leading families; apparently, this is conditioned by the natural and climatic conditions of the territory and peculiar features of the local flora.

In the composition of the alien flora, 177 genera are found, with more than half of them (103 genera, or $58 \%$ of the total number) being alien. The generic spectrum is headed by Amaranthus, which includes 6 species, 5 species are noted in Atriplex and Pinus, four species are represented by Populus, Salix, Sedum, Setaria and Xanthium, the remaining genera contain 3 or less alien species. It is characteristic that half of the genera leading in the number of species are the ones whose specific saturation is associated with a deliberate introduction: Pinus, Populus, Salix, Sedum.

An analysis of the alien species list according to the ratio of life forms demonstrates the prevalence of annual and biennial grasses (46.2\% in total); the second position is taken by perennial grasses (23.7\%), trees account for $15.6 \%$ of the alien flora, shrubs comprise $12.6 \%, 5$ species $(1.9 \%)$ refer to the life form of lignified lianas.

A typological analysis of the Nature Reserve Fund alien flora according to the time of invasion shows a clear predominance of euneophytes - this group of species accounts for $73.7 \%$ of the entire alien flora. The proportion of ancient aliens is only 9.5\% (see Table 5, Fig. 2).

A similar ratio was noted for the alien flora of the Voronezh region, where the proportion of archaeophytes was $7.8 \%$. The number of alien species that appeared in the flora over the last 100 years is 4.6 times larger than the number of aliens of the previous three centuries. Naturally, the intensity of floristic surveys of the regional flora in the last 100 years is much higher than before. In addition, perhaps, we do not take into account all ancient species being invaders. Thus, in the Nature Reserve Fund the alien flora of the plains of Ukraine, the proportion of archaeophytes reaches one-third (Burda et al., 2015). In the alien flora of three PAs of the Middle Volga region, the proportion of archaeophytes reaches $64.3 \%$ (Dronin, 2014). This is explained by the fact that some botanists consider a fairly large group of species to be archaeophytes, which we consider as part of the autochthonous element of the flora (Grigoryevskaya et al., 2004).

The list of the alien flora found in the Voronezh region NRF shows that $42 \%$ of the species appeared in the PAs as a result of spontaneous invasion, a third of the species have left the cultivation zone, and 15\% were deliberately planted in these territories. Alternatively, these plantations have been preserved since the time when the territories did not have the status of PAs yet. For seven species $(2.7 \%)$ there is no exact information about the way of their occurrence in PAs (Fig. 3). 22 Species (8.4\%) represent a mixed type of invasion. These are the plants that were deliberately planted in some PAs, thus demonstrating themselves as ergasiolypophytes, and the ones that left the cultivation zone in other PAs. Another example concerns species originally planted in some PAs which later left the cultivation zones and are now being transferred spontaneously from the secondary habitat by natural agents (Acer negundo, Amelanchier spicata). Thus, the appearance of the majority of alien species $(55 \%)$ in the PAs is associated with purposeful human activity aimed at the introduction of plants.

The most important characteristic of alien species is the degree of naturalisation, which indicates the success of their introduction and resettlement in ecosystems. In the Voronezh region NRF, unstable secondary areal species, such as ephemerophytes and colonophytes, account for $51.6 \%$ of the alien flora (Fig. 4). Ephemerophytes constitute a large group (68 species) of mainly annual herbaceous plants grown in the region as cereals, vegetables, fodder crops and ornamental plants. The group of ephemerophytes also includes certain weeds that harm the previously mentioned plants. 
Table 5. Nature Reserve Fund's alien flora (Voronezh Region) classification groups according to the time and ways of invasion, as well as ways of naturalising

\begin{tabular}{|c|c|c|c|c|c|c|c|c|c|c|}
\hline \multirow{2}{*}{\multicolumn{2}{|c|}{$\begin{array}{c}\text { Types according to the extent of } \\
\text { naturalisation }\end{array}$}} & \multicolumn{4}{|c|}{$\begin{array}{l}\text { Types according to the time of } \\
\text { invasion }\end{array}$} & \multicolumn{5}{|c|}{ Types according to the way of invasion } \\
\hline & & \multirow{2}{*}{ 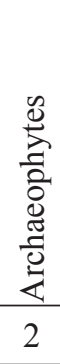 } & \multirow{2}{*}{ 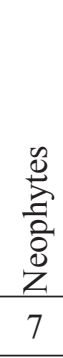 } & \multirow{2}{*}{ 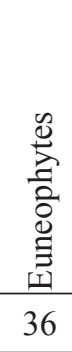 } & \multirow{2}{*}{$\begin{array}{l}\tilde{z} \\
0 \\
\vdots \\
\text { J } \\
-\end{array}$} & \multirow{2}{*}{ 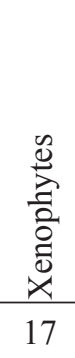 } & \multirow{2}{*}{ 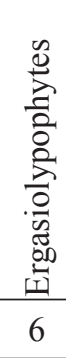 } & \multirow{2}{*}{ 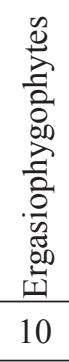 } & \multirow{2}{*}{ 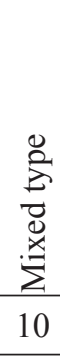 } & \multirow{2}{*}{3} \\
\hline Agriophytes & $46 / 17.6 \%$ & & & & & & & & & \\
\hline Epeco-agriophytes & $26 / 9.9 \%$ & 3 & 8 & 15 & - & 16 & - & 7 & 3 & - \\
\hline Epecophytes & $55 / 21.0 \%$ & 4 & 9 & 41 & 1 & 39 & 1 & 14 & 1 & - \\
\hline Colonophytes & $67 / 25.6 \%$ & - & 7 & 60 & 1 & 6 & 32 & 19 & 7 & 3 \\
\hline Ephemerophytes & $68 / 26 \%$ & 16 & 11 & 41 & - & 33 & - & 33 & 1 & 1 \\
\hline Total & 262 & 25 & 42 & 193 & 2 & 111 & 39 & 83 & 22 & 7 \\
\hline
\end{tabular}

A quarter of the alien flora (57 species) are colonophytes. These are mainly trees and shrubs planted before the formation of the reserves or during the period of their existence. Due to a long life span, such plants continue growing on the same sites for several decades without extending to other areas by self-sowing. Some species have already disappeared from the flora in this area. In the Voronezh Nature Reserve, for instance, a number of tree and shrub species died after several years or even decades after planting. These include Aralia elata (Miq.) Seem., Cotinus coggygria, Elaeagnus angustifolia L., Hippophaërhamnoides L., Juglans cinerea, Lespedeza bicolor Turcz., Pinus banksiana Lamb., P. koraiensis Siebold \& Zucc. Some perennial herbaceous species, e.g. Muscari neglectum Guss., and Paeonia lactiflora Pall., which

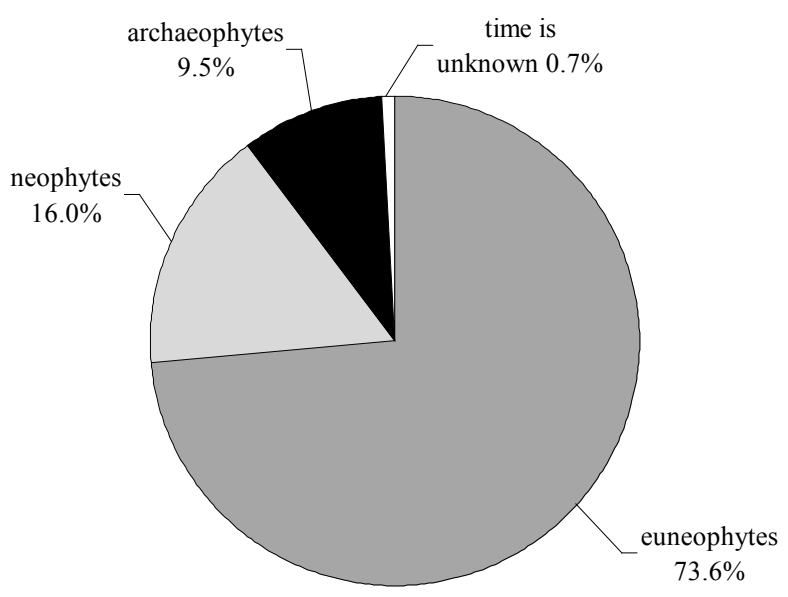

Fig. 2. Typological structure of the alien flora according to the time of invasion. had long existed in secondary habitats, have also disappeared (Starodubtseva, 2013). Such colonophytes as Chaenomeles japonica (Thunb.) Lindl. ex Spach, Syringa vulgaris L., Tulipa $\times$ hybrida are found in forest clearings where forest protection cordons used to be located. Similarly, plants of Caragana arborescens Lam. are occasionally found in artificial pine forests, where they had been planted to enrich the soil with nitrogen.

One-third of all alien species have been naturalised in disturbed and secondary habitats. According to the time of invasion, euneophytes prevail (74.5\%) among epecophytes. As for the way of invasion, the prevailing plants are xenophytes $(69 \%)$. Slightly more than a quarter of the epecophytes $(26 \%)$ is made by naturalised ergasiophygophytes.

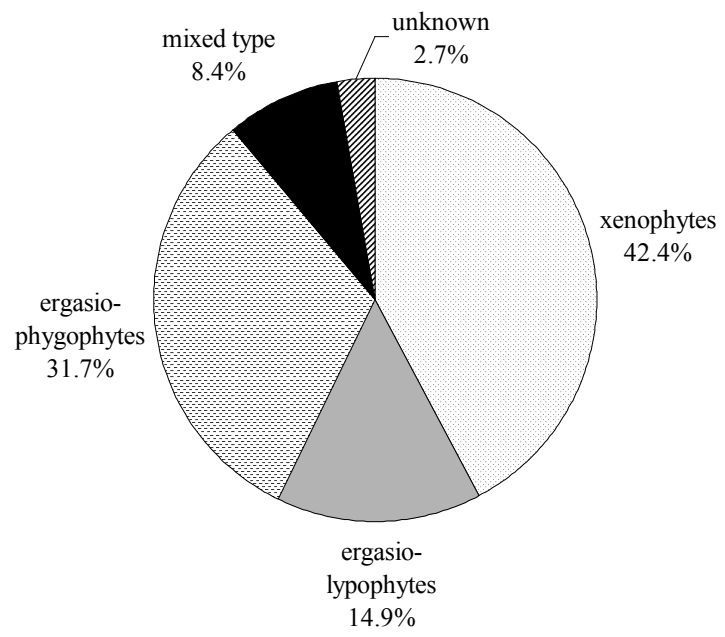

Fig. 3. Typological structure of alien flora according to the way of invasion. 


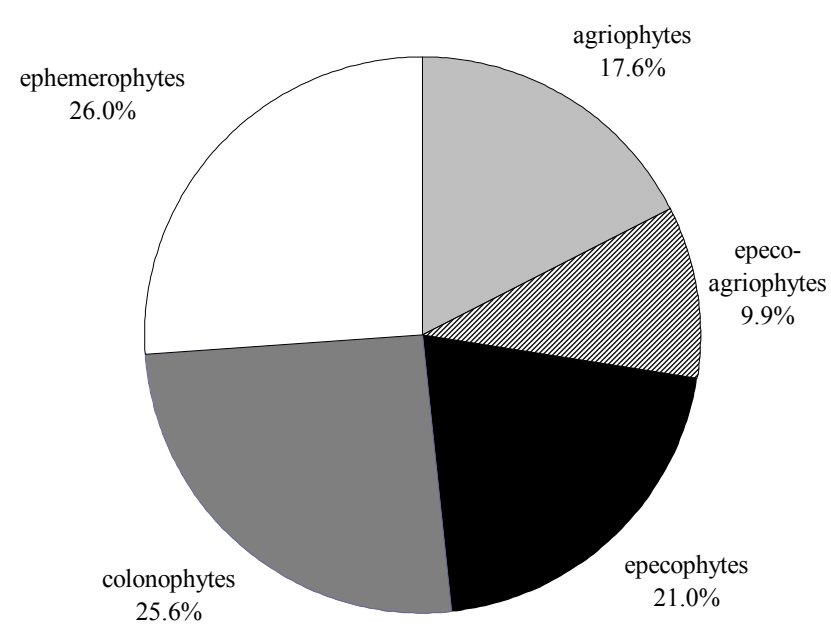

Fig. 4. Typological structure of alien flora according to the degree of naturalisation.

The group of agriophytes comprises 46 species $(17.6 \%$ of the entire alien flora). In general, this group is rather heterogeneous in terms of plant occurrence within the NRF territory and their phytocoenotic significance in the composition of plant communities. Most of the agriophytes (24 species) are found in the flora of one or two PAs only; 9 species occur in 3 PAs, 3 species are registered in 4 PAs, 6 species are found in 5 PAs, and 4 species occur in the flora of 6 PAs. There is a tendency of increasing in the proportion of species characterised by a high degree of naturalisation (agriophytes), from archeophytes (8\%) to neophytes $(16.6 \%)$ and euneophytes $(18.7 \%)$; at the same time, there is a significant reduction in the proportion of ephemerophytes: $64 \%-26 \%$ - $21 \%$, respectively. As for the ancient aliens, only two species got assimilated in natural communities: Salix fragilis L. and Acorus calamus L. At the same time, it is worth noting that whereas the spontaneously spread Acorus calamus occurs in Divnogorye only as «a rare species, sometimes in considerable numbers» (Chernobylova et al., 2000), Salix fragilis is a common species of floodplain communities in some PAs (Voronezh Nature Reserve, Voronezhsky Nature Sanctuary and Khoper Reserve). That is due to a mass planting in order to provide a beaver feeding source in the first half of the 20th century. As for neophytes, seven species have got naturalised in natural plant communities, and there are 36 species of this type among the latest «newcomers» of the $20^{\text {th }}$ century.

An important regularity that characterises the process of flora adventisation in the Voronezh region is that ergasiophytes predominate among the species naturalised in natural communities, while xenophytes predominate among the alien species naturalised in secondary habitats and disturbed communities (Fig. 5). This indicates that the PAs plant communities still maintain resistance to spontaneously spreading alien species, but are not able to resist the penetration of species specially selected for cultivation in forest-steppe climatic conditions.

Special attention should be paid to transformer species, i.e. alien plants, which get actively introduced into plant communities, modifying the physiognomy and nature of ecosystems and change succession links. Such plants are able to become edificators, forming monodominant communities and preventing the renewal of species of the natural flora. Among the agriophytes found in PAs, the following 13 species are characterised as transformers: Bidens frondosa L., Phalacroloma annuum (L.) Dumort., Ph. septentrionale (Fernald \& Wiegand) Tzvelev, Elodea canadensis Michx., Epilobium adenocaulon Hausskn., E. pseudorubescens A. Skvortz, Salix fragilis, Robinia pseudoacacia, Amelanchier spicata, Sambucus racemosa, Parthenocissus inserta (A. Kern.) Fritsch, P. quinquefolia (L.) Planch, Echinocystis lobata (Michx.) Torr. \& Gray. The group of alien plants naturalised in disturbed habitats and natural phytocenoses in PAs, includes such transformers as Acer negundo, Xanthium albinum (Widd) H. Scholz, X. ripicola Holub, Oenothera biennis L. As for epecophytes, the transformer plants are Conyza canadensis (L.) Cronqist and Cyclachaena xanthiifolia (Nutt.) Fresen. Of the total 19 transformer species, 11 are xenophytes, and 8 are ergasiophytes.

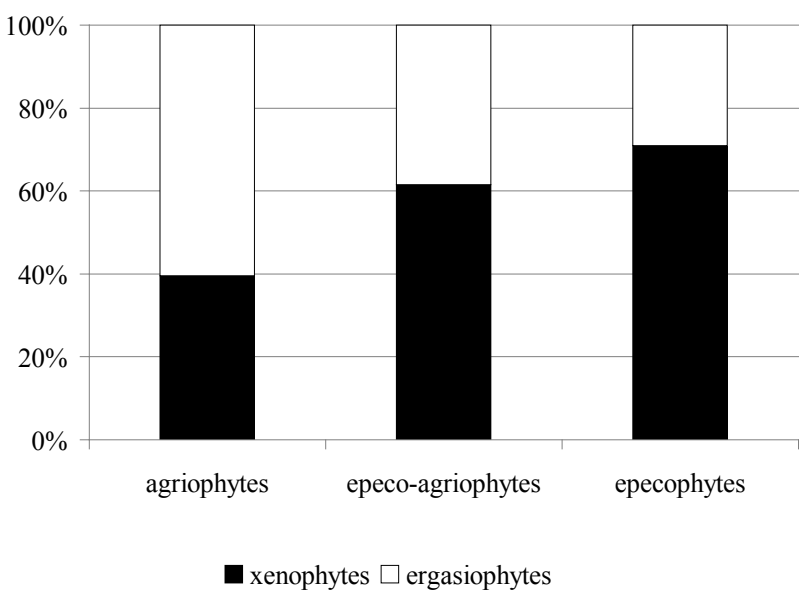

Fig. 5. The proportion of spontaneous alien species and introduced species in alien groups naturalised in natural communities and disturbed habitats. 
Special consideration has to be given to the situation on the territories of state reserves. Thus, the forest inventory conducted in 2013 in the Voronezh Reserve, revealed the presence of forest plots where the predominant species are Robinia pseudoacacia and Acer negundo. The forests where Acer negundo forms the lower arborescent stratum were described. In Khoper Nature Reserve this species has already spread within all floodplain forests, pine forests on the left-bank terraces of the River Khoper, oak forests and among ash trees on the right bank slopes and ravines (Neskryabina et al., 2012). Another species that changes the look of the floodplain forests and meadows of the Khoper reserve is Parthenocissus inserta; similarly, $P$. quinquefolia becomes a component of pine forests in the outskirts of the Voronezh Reserve. In both reserves, Bidens frondosa has now become a common species as well (Neskryabina et al., 2012).

In addition to transformer species, Cerasus vulgaris Mill and Ulmus pumila L. also possess a high invasive potential. These species are found in practically all forest-protecting PAs. They are rarely encountered in natural phytocenoses, but in secondary habitats, the frequency of their appearance is much higher.

Special features of alien fractions of local floras in model PAs. In the Voronezh Region, from 10 to 174 species are registered in the local flora of the specially protected natural areas. The proportion of the alien fraction is averaged to $11.1 \%$, varying from $4.4 \%$ to $16.8 \%$ (see Table 3). The proportion of alien species in the PAs of Europe is within the range of $0-18 \%$ (model PAs of France (3 PAs), the United Kingdom (3), Czech Republic, Germany, Italy, Portugal (1 PA in each country) were included in the analysis). $40 \%$ Of alien species are reported only in the flora of Sefton Coast PA (UK); scientists explain this by including also casual alien plants (Pyšek et al., 2013). The proportion of alien species in PAs of the Czech Republic is averaged to $6.1 \%$ $(0-25 \%)$, while $11.6 \%$ of all nature reserves with different nature protection status (out of 302 surveyed) are free from any alien species (Pyšek et al., 2002b). In the 37 reserves of European Russia, the proportion of alien species ranges from 1.6 to $21.8 \%$, which makes the average of $8.5 \%$ (Morozova \& Tsarevskaya, 2010). Higher rates were recorded in the Nature Reserve Fund of the forest-steppe part of Ukraine, where the proportion of alien species averaged to $16 \%$ (from 9 to $28 \%$ ) (Petrovich et al., 2014). The proportion of alien species in the forest-steppe and two steppe nature monuments of the Middle Volga region is $12.3 \%, 13.2 \%$ and $8.7 \%$, respectively (Dronin, 2014). A higher proportion of alien species in the local flora of the forest-steppe and steppe PAs of Ukraine and the Middle Volga region in comparison with the PAs of the Voronezh region is mainly due to the different understanding of the volume of the archaeophytes group (this has already been noted above). Thus, the proportion of alien species in the local flora of the Voronezh Region PAs is slightly higher than the average in the flora of the European PAs and comparable to the data on the flora of PAs protecting forest-steppe and steppe ecosystems.

Most alien species are registered in the flora of state reserves and state nature sanctuaries. This is due, on the one hand, to the fact that these PAs occupy a large area and are therefore characterised by a higher ecotopic and ecosystem diversity. On the other hand, in the Voronezh Region state reserves intensive economic activity, including intentional enrichment of protected natural complexes with alien species had been conducted for a long time. A greater number of alien species in the reserves is also due to annual monitoring of biological diversity conducted in these territories for many decades. The degree of flora familiarisation and the proportion of identified alien species is much higher here than in places, where surveys were conducted just occasionally.

The analysis of the local flora of the Voronezh PAs (Fig. 6) that included the proportion of stable alien species (epekophytes, epeko-agriophytes and agriophytes) only, allows to take into account that a significant number of alien ephemerophytes previously found in the reserves have now disappeared from the reserves' flora (Starodubtseva, 2016). At the same time, the proportion of alien species in the protected flora is rather low, averaging to $6.1 \%$ (from $3.5 \%$ to $8.9 \%$ ).

Most of the alien species are not widely distributed in the PAs: 100 species (38\% of the total alien flora) has only been found in one PA; 63 species $(24 \%)$ are registered in two PAs. Polygonum aviculare L. is the only species found in every model PA. 27 Species show a high stability of occurrence $(50 \%$ or higher) in the PAs' floras. Generally, these are widely spread weeds and ruderal xenophytes (see Table 6), however Acer negundo, a North American alien transformer species, also shows a high occurrence stability and can be found in 11 of 16 model PAs. 


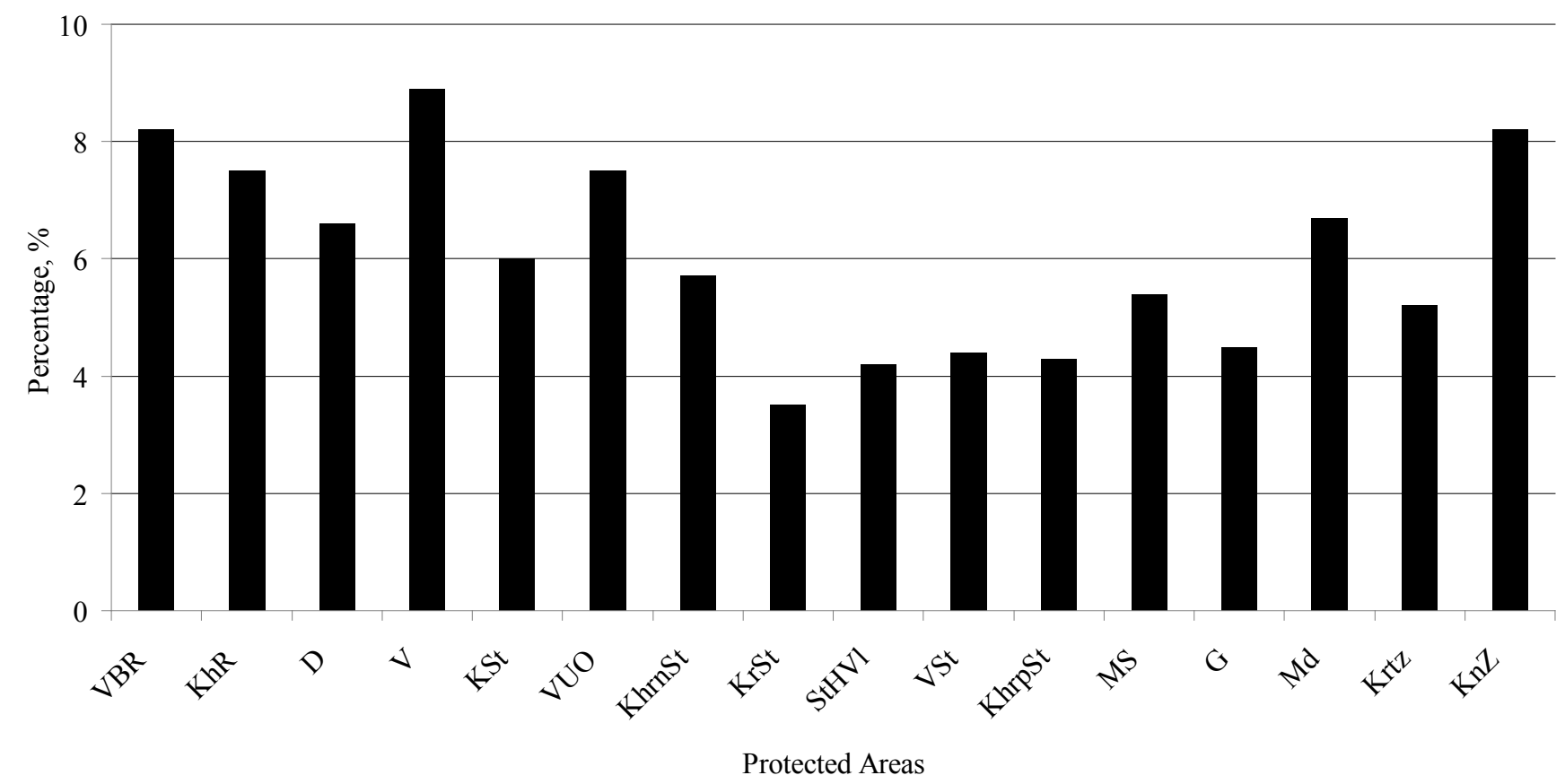

Fig. 6. Proportion of alien species characterised by a stable secondary habitat in the model PAs floras (\%). VBR - Voronezh State Nature Biosphere Reserve; KhR - Khoper State Nature Reserve; D - State open-air museum of architecture and archeology «Divnogorye»; V - State federal-level nature sanctuary «Voronezhsky»; KSt - State federal-level nature sanctuary «Kamennaya Steppe»; VUO - Regional-level nature sanctuary «Voronezh uphill oakery»; Regional-level natural monuments: KhrnSt - Khrenovskaya Steppe; KrSt - Krasnyanskaya Steppe; StHVI - Steppe Hillslopes by Vladimirovka settlement; VSt - Volokonovskaya Steppe; KhrpSt - Khripunskaya Steppe; MS - Melovaya Sosna; G - Golik; Krtz - Krutzy; Md - Maydan; KnZ - Kreyda na Zapadne.

Table 6. Most common alien species in the floras of the model Protected Areas

\begin{tabular}{|c|c|}
\hline Species & Number of PAs \\
\hline Polygonum aviculare L. & 16 \\
\hline Bromus japonicus Thunb. & \multirow{3}{*}{15} \\
\hline Bromus squarrosus L. & \\
\hline Echinochloa crusgalli (L.) Beauv. & \\
\hline Thlaspi arvense L. & 14 \\
\hline Amaranthus retroflexus L. & 13 \\
\hline Lactuca serriola L. & \multirow{7}{*}{12} \\
\hline Lepidotheca suaveolens (Pursh) Nutt. & \\
\hline Bunias orientalis L. & \\
\hline Lepidium densiflorum Schrad. & \\
\hline Atriplex tatarica $\mathrm{L}$. & \\
\hline Stachys annua (L.) L. & \\
\hline Setaria viridis (L.) Beauv. & \\
\hline Acer negundo L. & \multirow{2}{*}{11} \\
\hline Lactuca tatarica (L.) C.A. Mey. & \\
\hline Setaria pumila (Poir.) Schult. & 10 \\
\hline Centaurea cyanus L. & \multirow{6}{*}{9} \\
\hline Conyza canadensis (L.) Cronq. & \\
\hline Onopordum acanthium L. & \\
\hline Saponaria officinalis L. & \\
\hline Nepeta cataria L. & \\
\hline Malva pusilla Smith & \\
\hline Eragrostis minor Host & \multirow{5}{*}{8} \\
\hline Medicago sativa L. & \\
\hline Reseda lutea $\mathrm{L}$. & \\
\hline Senecio vernalis Waldst. \& Kit. & \\
\hline Silene dichotoma Ehrh. & \\
\hline
\end{tabular}

According to the similarity of the alien flora lists, the model PAs can be divided into three groups. The first group consists of the alien flora found in steppe nature monuments (Khrenovskaya Steppe, Krasnyanskaya Steppe, Volokonovskaya Steppe, Khripunskaya Steppe, Hillslopes by Vladimirovka settlement). These areas demonstrate the highest similarity index $(0.42-0.68)$. The second group includes the typical foreststeppe nature monuments of Pridonskoy chalk region (Mordva, Maydan, Krutzy), as well as southern forest-steppe nature monuments (Golick and Kreyda na Zapadne) that protect calcareous steppe and lowered alpine plants. The alien flora of this group shows a relatively high similarity index $(0.41-0.64)$. The third group includes reserves, Divnogorye and sanctuaries (similarity index 0.33-0.41). Voronezh PAs alien flora similarity analysis reflects peculiarities of the adventisation process in a different landscape and phytocoenotic forest-steppe environment.

\section{Conclusions}

The research reveals the composition of alien species in the flora of 16 model objects of Voronezh Region Nature Reserve Fund. The taxonomic diversity of the studied floras comprises 262 taxa, includ- 
ing 255 species, 5 hybrids, 1 subspecies and 1 variety, which involve 178 genera and 66 families.

In the floras of model PAs, $58 \%$ of all the alien species recorded in the flora of the region were detected. The average proportion of invasive species in PAs' flora lists is $11.1 \%$ (in different local floras it varies from $4.4 \%$ to $16.8 \%$ ). If to consider stable flora elements only (excluding ephemerophytes and colonophytes), then the PAs local flora contamination ratio will make the average of $6.1 \%$ (from $3.5 \%$ to $8.9 \%$ ).

The largest number of alien species is noted in the floras of state reserves and state nature sanctuaries, although these PAs have a stricter protective regime for natural complex protection. There are several reasons for this: 1) these PAs occupy a large area and are therefore characterised by a higher ecotopic and ecosystem diversity; 2) the exploration degree of floras in these territories is much higher; 3) reserves and sanctuaries were created in areas significantly transformed by economic activity in the past; 4) in the first decades of these PAs' existence many tree and shrub species were deliberately introduced into protected phytocoenoses. The high degree of contamination of local floras in federal PAs by alien species casts doubt on the reference character of protected natural complexes and their management efficiency.

$42 \%$ Of invasive species appeared in the PAs as a result of spontaneous invasion, $31.7 \%$ of alien species are the ones that had left the cultivation area, $15 \%$ were deliberately planted, for 7 species $(2.7 \%)$ the way they came to the area is unknown, and 22 species $(8.4 \%)$ are characterised by a mixed way of introduction. The analysis of the alien species' ways of appearance proves that a large contribution to the enrichment of alien flora is made by human activities on the introduction and cultivation of plants. Whereas spontaneous invasion of species to PAs can hardly be prevented, the fallout of cultivation and extinction of ornamental and fruit plants can be controlled and can be avoided in most cases.

As a result of the analysis of the degree of alien species naturalisation it has been revealed that protected natural plant communities are still resistant to spontaneous introduction of alien species. A large number of alien species with a high degree of naturalisation belongs to the group of ergasiophytes. Transformers are of the greatest coenotic significance, out of 19 such alien species 11 are xenophytes and 8 species are ergasiophytes. In the federal PAs of the Voronezh region, which protect forest ecosystems, the formation of forests with alien species predominance was noted, and changes in the structure of plant communities caused by the impact of alien species were described. At present, the change of dominants in different synfolia of protected phytocenoses becomes a real possibility. The most successful invasive species in the preserved nature areas of Voronezh Region are the following: Acer negundo, Parthenocissus inserta, Parthenocissus quinquefolia, Amelanchier spicata, Robinia pseudoacacia, Sambucus racemosa, Bidens frondosa, and Fraxinus pennsylvanica.

For the state reserves of the Voronezh region, a demand has arisen to move from monitoring alien species to practical working on managing the process of alien plant invasion. Programs for the prevention of biological invasions should be part of the management plans of the PAs, and be included in government tasks for institutions that manage PAs. It is also important to forbid cultivating invasive species in the areas of nature reserves nor anywhere near PAs borders. To achieve such a complicated goal, complex measures have to be taken. These suppose developing ecological awareness of the local residents, getting local authorities support the PA-bordering territories. It will be necessary to study and implement the international experience in the removal of alien species from the places of their local growth in PAs.

\section{Acknowledgements}

We thank two anonymous reviewers for helpful comments on the manuscript. The work was supported by the grant 14-04-90403 of the joint Ukrainian-Russian research project of the NAS of Ukraine and the RFBR in 2014-2015.

\section{References}

Agafonov V.A. 2003. On flora of the Krasnyansk steppe. Vestnik of the Voronezh State University. Series: Chemistry, Biology, Pharmacy 2: 91-94. [In Russian]

Agafonov V.A. 2004. Grass family (Gramineae Juss., Poaceae Barnh.) of the Usman pinewoods: about flora of the educational scientific biological centre of VSU «Venevitinovo» precincts. Vestnik of the Voronezh State University. Series: Chemistry, Biology, Pharmacy 2: 90-98. [In Russian]

Akhtyrtsev B.P., Akhtyrtsev A.B. 1993. Central Russian Black Earth topsoil. Voronezh: Voronezh University Publisher. 216 p. [In Russian]

Allen J.A., Brown C.S., Stohlgren T.J. 2009. Non-native plant invasions of United States National Parks. Biological Invasions 11: 2195-2207. DOI:10.1007/s10530-008-9376-1

Barabash G.I., Kamaeva G.M., Mayorov S.R., Khlyzova N.Yu. 2008. Vascular plant list of the educational sci- 
entific biological centre of Voronezh State University «Venevitinovo». Preliminary results. Moscow: MAKS Press. 44 p. [In Russian]

Bukhalo M.A. 1989. Systematical structure of the native flora of the Central Black Earth region in connection with its floristic zonation. Botanicheskiy Zhurnal 74(5): 638-650. [In Russian]

Burda R.I. 2014. Integration of invasive alien species control into the management system of the Protected Areas. Ekosistemy 10: 208-220. [In Russian]

Burda R.I., Golivets M.A., Petrovich O.Z. 2015. Alien species in the flora of the nature reserve fund of the flatland part of Ukraine. Russian Journal of Biological Invasions 6(1): 6-20. DOI: 10.1134/S2075111715010038

Chernobylova M.V., Agafonov V.A., Khmelev K.F. 2000. Flora of key sites of ecological network in the southern part of Voronezh region (annotated list of species). Voronezh: Voronezh State University. 58 p. [In Russian]

De Poorter M., Pagad S., Ullah M.I. 2007. Invasive alien species and protected areas: a scoping report. Produced for the World Bank as a contribution to the Global Invasive Species Programme (GISP), ISSG IUCN. 93 p.

Dronin G.V. 2014. Alien (adventive) plant species in the flora of Protected Areas in the Syzranka river basin (Zasyzranye district). Samarskaya Luka: problems of regional and global ecology 23(3): 103-111. [In Russian]

Egorov V.N., Treshchevskiy I.V., Shatalov V.G. 1967. Fieldprotecting and floodplain forestation. Voronezh: TsentralnoChernozemnoe knizhnoe izdatelstvo. 116 p. [In Russian]

Fedotov V.I. (Ed.). 2013. Ecological Geographical atlas of the Voronezh region. Voronezh: Voronezh State University. 514 p. [In Russian]

Flora of the European part of the USSR. Volumes 1-9. Leningrad: Nauka, 1974-1989. [In Russian]

Foxcroft L.C., Pyšek P., Richardson D.M., Genovesi P. (Eds.). 2013. Plant invasions in protected areas: patterns, problems and challenges. Dordrecht: Springer. 656 p. DOI: 10.1007/978-94-007-7750-7

Foxcroft L.C., Pyšek P., Richardson D.M., Genovesi P., MacFadyen S. 2017. Plant invasion science in protected areas: progress and priorities. Biological Invasions 19(5): 1353-1378. DOI: 10.1007/s10530-016-1367-z

Golitsyn S.V. 1961. Plant list of the Voronezh State Reserve. Proceedings of the Voronezh State Reserve 10: 1-101. [In Russian]

Grigoryevskaya A.Ya., Zelepukin D.S. 2013. Flora of oak forests in Voronezh urban district: biogeographical, ecological, environmental aspects. Voronezh: Voronezhskaya oblastnaya tipografiya. 260 p. [In Russian]

Grigoryevskaya A.Ya., Starodubtseva E.A., Khlyzova N.Yu., Agafonov V.A. 2004. Adventive flora of Voronezh region: historical, biogeographical, ecological aspects. Voronezh: Voronezh State University. 320 p. [In Russian]

Grigoryevskaya A.Ya., Gamaskova E.S., Pashchenko A.I., Chernukhin S.M. 2008. Synanthropic flora of the Research Institute of Agriculture of the Central Black Earth
Region named after V.V. Dokuchaev. Voronezh region Kamennaya steppe. Flora and vegetation of the Central Black Earth region - 2008. Kursk. P. 6-13. [In Russian]

Holub J., Jirásek V. 1967. Zur Vereinheitlichung der Terminologie in der Phytogeographie. Folia Geobotanica et Phytotaxonomica 2(1): 69-113.

Kamyshev N.S. 1953. Kamennaya steppe natural flora characteristics. Proceedings of Voronezh State University 28: 143-144. [In Russian]

Kamyshev N.S. 1955. Natural flora analysis of the Khrenovskaya steppe. Proceedings of Voronezh State University 42(1): 35-36. [In Russian]

Kamyshev N.S. 1971. Kamennaya and Khrenovskaya steppe flora of the Voronezh region. In: Scientific notes of the Voronezh branch of the All-Union Botanical Society. Voronezh. P. 31-54. [In Russian]

Kozhevnikova L.I., Chagarnaya Z.V. 1986. Dynamics of Khrenovskaya steppe flora. In: Study and protection of small protected areas nature. Voronezh. P. 77-84. [In Russian]

Lepeshkina L.A. 2012. Plant invasions problems in Protected Areas of the Middle Russian forest-steppe. In: Modern problems of introduction and conservation of plant biodiversity: Materials of the $2^{\text {nd }}$ International Scientific Conference dedicated to the $75^{\text {th }}$ anniversary of the Botanical gardens named after professor B.M Kozo-Polyanskyi and centenary of the S.I. Mashkin's birth (Voronezh, 3-5 October, 2012). Voronezh. P. 53-57. [In Russian]

Lepeshkina L.A., Grigoryevskaya A.Ya, Klevtsova M.A., Voronin A.A. 2014. Invasive dendroflora of the Middle Russian forest-steppe: structural and biogeographical factors of research. Tambov University Vestnik. Series: Natural Sciences and Technology 19(5): 1524-1528. [In Russian]

Maevskiy P.F. 2014. Flora of Middle belt of the European part of Russia. Moscow: KMK Scientific Press Ltd. 635 p. [In Russian]

Mashkin S.I. 1952. Wild and cultural trees and bushes of Voronezh region. In: Voronezh Region trees and bushes: Proceedings of Voronezh University Botanical Garden. Voronezh. P. 18-176. [In Russian]

McNeely J.A., Mooney H.A., Neville L.E., Schei P., Waage J.K. (Eds.). 2001. A Global Strategy on Invasive Alien Species. Gland, Switzerland and Cambridge, UK: IUCN. 50 p.

Monaco A., Genovesi P. 2014. European guidelines on Protected Areas and invasive alien species. Strasbourg, France and Lazio Region, Rome, Italy: Council of Europe and Regional Parks Agency. 58 p.

Morozova O.V. 2003. Adventive species' contribution to the formation of diversity and structure of the Eastern Europe floras. Izvestia of Russian Academy of Sciences/ Geographical series 3: 63-71. [In Russian].

Morozova O.V. 2008. Eastern Europe's taxonomic richness: Factors of territorial differentiation. Moscow: Nauka publ. 328 p. [In Russian].

Morozova O.V., Starodubtseva E.A., Tsarevskaya N.G. 2008. Adventive flora of the European part of Russia. Izvestia 
of Russian Academy of Sciences. Geographical series 5: 85-94. [In Russian]

Morozova O.V., Tsarevskaya N.G. 2010. Invasive species' contribution to reserves' flora. Izvestia of Russian Academy of Sciences. Geographical series 4: 54-62. [In Russian]

Negrobov O.P. (Ed.). 2001. The cadastre of Protected Areas of Voronezh region. Voronezh: Voronezh State University. 146 p. [In Russian]

Neskryabina E.S., Pechenyuk E.V. 1997. About floristic findings in the Khoper Reserve. In: Problems of preserving and evaluating the state of the natural complexes and objects. Voronezh. P. 97-98. [In Russian]

Neskryabina E.S., Pechenyuk E.V. 2012. A new in the flora of the Khoperskyi Reserve and its vicinity. Proceedings of Khoper state reserve 7: 139-144. [In Russian]

Neskryabina E.S., Pechenyuk E.V., Rodionova N.A. 2012. The expansion of some invasive plants at the territory of the Khoper State Reserve. In: Anthropogenic influence on flora and vegetation: Materials of the $3^{\text {rd }}$ scientificpractical regional conference (February, 17-18, 2012 Lipetsk). Lipetsk. P. 30-34. [In Russian]

Pechenyuk E.V. 1997. Analytical review of the amendments to the list of the hydrophytes in the Khoper State Reserve. In: Problems of preserving and evaluating the state of the natural complexes and objects: Materials of the scientific-practical conference dedicated to 70-year anniversary of the Voronezh State Nature Biosphere Reserve (Voronezh, Grafskaya station, September, 8-11, 1997). Voronezh. P. 92-93. [In Russian]

Petrovich O.Z., Burda R.I., Pashkevich N.A., Golivets M.A. 2014. Preconditions for the establishment of forest steppe non-native floras of the protected areas of Ukraine. Chornomorski Botanical Journal 10(3): 388-401. DOI: 10.14255/2308-9628/14.103/11 [In Ukrainian]

Ponert J. 1977. Ergasiophygophytes and Xenophytes of East Asiatic Origin in Adjaria. A Stimulus to New Terminology, Especially for Ergasiophygophytes. Folia Geobotanica et Phytotaxonomica 12: 9-22.

Prokhorova O.V., Grigoryevskaya A.Ya. 2007. Biogeografic peculiarities of the Voronezh region steppes flora. Vestnik of the Voronezh State University. Series: Geography. Geoecology 2: 26-36. [In Russian]

Pyšek P., Sádlo J., Mandák B. 2002a. Catalogue of alien plants of the Czech Republic. Preslia 74: 97-186.

Pyšek P., Jarošik V., Kučera T. 2002b. Patterns of invasion in temperate nature reserves. Biological Conservation 104: 13-24. DOI: 10.1016/S0006-3207(01)00150-1

Pyšek P., Jarošik V., Kučera T. 2003. Inclusion of Native and Alien Species in Temperate Nature Reserves: an Historical Study from Central Europe. Conservation Biology 17(5): 1414-1424.

Pyšek P., Genovesi P., Pergl J., Monaco A., Wild J. 2013. Plant Invasions of protected areas in Europe: an old continent facing new problems. In: L.C. Foxcroft, P. Pyšek, D.M. Richardson, P. Genovesi (Eds.): Plant invasions in protected areas: patterns, problems and challenges. Dordrecht: Springer. P. 209-240. DOI: 10.1007/978-94-007-7750-7_11

Report on environmental situation in the Voronezh region in 2014. Voronezh regional department of natural resources and Ecology. Voronezh: Voronezh State University, 2015. 232 p. [In Russian]

Richardson D.M., Pyšek P., Rejmánek M., Barbour M.G., Panetta F.D., West C.J. 2000. Naturalization and invasion of alien plants: conception and definitions. Diversity and distribution 6: 93-107.

Rikli M. 1903. Die Anthropochoren und der Formenkreis des Nasturtium palustre DC. Berichte der Zürcher Botanischen Gesellschaft 8: 71-82.

Rodionova N.A. 2000. Cultivated species of plants as potential invasive plants in the reserve's community. In: Status, research and preservation of the reserved natural complexes of the forest-steppe zone. Voronezh. P. 63-66. [In Russian]

Starodubtseva E.A. 1999. Vascular plants. In: Flora of the Voronezh State Reserve. Vol. 78. Moscow. P. 5-96. [In Russian]

Starodubtseva E.A. 2007. Additions and amendments to the list of Voronezh Reserve vascular plants. Proceedings of the Voronezh State Reserve 24: 74-92. [In Russian]

Starodubtseva E.A. 2011. Alien flora of protected territories (by the example of the Voronezh Biosphere Reserve). Russian Journal of Biological Invasions 2(4): 265-267. DOI: $10.1134 /$ S2075111711040114

Starodubtseva E.A. 2012. Addition to flora of the vascular plants in Voronezh Reserve. Proceedings of Voronezh State Reserve 26: 55-64. [In Russian]

Starodubtseva E.A. 2013. Naturalisation of invasive plants in the Voronezh Reserve. Central Black Earth region flora and vegetation - 2013. Kursk. P. 183-188. [In Russian]

Starodubtseva E.A. 2016. Species extinction in protected areas (Voronezh reserve, 1935-2015). Russian Journal of Ecosystem Ecology 1(4). DOI:10.21685/2500-05782016-4-4. [In Russian]

Takhtajan A.L. 1978. The floristic regions of the World. Leningrad: Nauka. 347 p. [In Russian]

Thellung A. 1918-1919. Zur Terminologie der Adventiv- und Ruderalflora. Allgemeine Botanische Zeitschrift für Systematik, Floristik, Pflanzengeographie 24/25: 36-42.

Tzvelev N.N. 1988. Flora of the Khoper State Reserve. Leningrad: Nauka. 191 p. [In Russian]

Tzvelev N.N. (Ed.). 1996. Flora of Eastern Europe. Vol. 9. St.-Petersburg: Mir i Semja. 456 p. [In Russian]

Tzvelev N.N. (Ed.). 2001. Flora of Eastern Europe. Vol. 10. St.-Petersburg: Mir i Semja. 670 p. [In Russian]

Tzvelev N.N. (Ed.). 2004. Flora of Eastern Europe. Vol. 11. Moscow; St.-Petersburg: KMK Scientific Press Ltd. 536 p. [In Russian]

Vinogradova Yu.K., Mayorov S.R., Khorun L.V. 2010. The Black Book of flora of Central Russia: alien plant species in ecosystems of Central Russia. Moscow: GEOS. 511 p. [In Russian] 
Appendix. The total list of species and their distribution in Protected Areas of Voronezh region

\begin{tabular}{|c|c|c|c|c|c|c|c|c|c|c|c|c|c|c|c|c|c|}
\hline \multirow{2}{*}{ Families and species } & \multicolumn{16}{|c|}{ Presence in Protected Areas } & \\
\hline & 1 & 2 & 3 & 4 & 5 & 6 & 7 & 8 & 9 & 10 & 11 & 12 & 13 & 14 & 15 & 16 & \\
\hline \multicolumn{18}{|l|}{ Aceraceae } \\
\hline Acer ginnala Maxim. & - & - & - & - & + & + & - & - & - & - & - & - & - & - & - & - & 2 \\
\hline Acer negundo L. & + & + & + & + & + & + & + & + & + & + & + & - & - & - & - & - & 11 \\
\hline Acer pseudoplatanus L. & - & - & - & - & + & + & - & - & - & - & - & - & - & - & - & - & 2 \\
\hline \multicolumn{18}{|l|}{ Amaranthaceae } \\
\hline Amaranthus albus L. & + & + & - & - & + & - & - & - & - & - & - & - & - & - & - & - & 3 \\
\hline Amaranthus blitoides S. Wats. & + & + & + & - & + & - & - & - & - & - & - & + & - & - & - & - & 5 \\
\hline Amaranthus blitum L. & + & - & - & - & - & - & - & - & - & - & - & - & - & - & - & - & 1 \\
\hline Amaranthus caudatus L. & - & + & - & + & - & - & - & - & - & - & - & - & - & - & - & - & 2 \\
\hline Amaranthus cruentus L. & - & + & - & - & - & - & - & - & - & - & - & - & - & - & - & - & 1 \\
\hline Amaranthus retroflexus L. & + & + & + & + & + & - & + & + & + & + & + & + & - & + & + & - & 13 \\
\hline \multicolumn{18}{|l|}{ Anacardiaceae } \\
\hline Cotinus coggygria Scop. & + & + & - & - & + & - & - & - & - & - & - & - & - & - & - & - & 3 \\
\hline \multicolumn{18}{|l|}{ Apocynaceae } \\
\hline Vinca minor L. & + & - & - & - & - & + & - & - & - & - & - & - & - & - & - & - & 2 \\
\hline \multicolumn{18}{|l|}{ Araceae } \\
\hline Acorus calamus L. & - & - & + & - & - & - & - & - & - & - & - & - & - & - & - & - & 1 \\
\hline Pistia stratiotes L. & - & - & - & + & - & - & - & - & - & - & - & - & - & - & - & - & 1 \\
\hline \multicolumn{18}{|l|}{ Araliaceae } \\
\hline Aralia elata (Miq.) Seem. & + & - & - & - & - & - & - & - & - & - & - & - & - & - & - & - & 1 \\
\hline \multicolumn{18}{|l|}{ Asclepiadaceae } \\
\hline Cynanchum acutum L. & - & + & - & - & - & - & - & - & - & - & - & - & - & - & - & - & 1 \\
\hline \multicolumn{18}{|l|}{ Asteraceae } \\
\hline Ambrosia artemisiifolia L. & - & - & + & - & - & - & - & - & - & - & - & - & - & - & - & - & 1 \\
\hline Ambrosia trifida L. & + & - & - & - & - & - & + & - & - & - & - & - & - & - & - & - & 2 \\
\hline Anthemis arvensis L. & - & - & + & - & - & - & - & - & - & - & - & - & - & - & - & - & 1 \\
\hline Artemisia dubia Wall. & + & - & - & - & - & - & - & - & - & - & - & - & - & - & - & - & 1 \\
\hline Artemisia sieversiana Willd. & + & - & - & - & + & - & - & - & - & - & - & - & - & - & - & - & 2 \\
\hline Aster $x$ salignum Willd. & + & - & - & - & - & - & - & - & - & - & - & - & - & - & - & - & 1 \\
\hline Bidens frondosa $\mathrm{L}$. & + & + & + & + & - & + & + & - & - & - & - & - & - & - & - & - & 6 \\
\hline Calendula officinalis L. & - & - & - & + & - & - & - & - & - & - & - & - & - & - & - & - & 1 \\
\hline Centaurea cyanus L. & + & + & - & + & + & - & + & + & + & + & + & - & - & - & - & - & 9 \\
\hline Centaurea diffusa Lam. & - & + & - & - & + & - & - & - & - & - & - & - & - & - & + & - & 3 \\
\hline Centaurea majorovii Dumb. & - & + & - & - & + & - & - & - & - & - & - & - & - & - & - & - & 2 \\
\hline Conyza canadensis (L.) Cronq. & + & + & + & + & + & + & + & + & - & + & - & - & - & - & - & - & 9 \\
\hline Cosmos bipinnatus Cav. & + & - & - & + & - & - & - & - & - & - & - & - & - & - & - & - & 1 \\
\hline Cyclachaena xanthiifolia (Nutt.) Fresen. & + & + & + & + & + & + & - & - & - & - & - & - & + & - & - & - & 7 \\
\hline Galinsoga parviflora Cav. & + & - & - & + & + & + & - & - & - & - & - & - & - & - & - & - & 4 \\
\hline Helianthus annuus L. & + & - & + & + & - & - & + & - & - & - & - & - & - & - & - & - & 4 \\
\hline Helianthus subcanescens (A. Gray) E.E. Wats. & + & - & - & - & - & - & - & - & - & - & - & - & - & - & - & - & 1 \\
\hline Helianthus tuberosus L. & + & - & - & + & - & + & - & - & - & - & - & - & - & - & - & - & 3 \\
\hline Lactuca serriola L. & + & + & + & + & + & - & + & - & - & + & - & + & + & + & + & + & 12 \\
\hline
\end{tabular}




\begin{tabular}{|c|c|c|c|c|c|c|c|c|c|c|c|c|c|c|c|c|c|}
\hline \multirow{2}{*}{ Families and species } & \multicolumn{16}{|c|}{ Presence in Protected Areas } & \multirow{2}{*}{$*$} \\
\hline & 1 & 2 & 3 & 4 & 5 & 6 & 7 & 8 & 9 & 10 & 11 & 12 & 13 & 14 & 15 & 16 & \\
\hline Lactuca tatarica (L.) C.A. Mey. & + & + & + & + & + & + & + & - & + & + & + & - & + & - & - & - & 11 \\
\hline Lepidotheca suaveolens (Pursh) Nutt. & + & + & + & + & + & + & + & + & + & + & + & - & + & - & - & - & 12 \\
\hline Matricaria recutita $\mathrm{L}$. & - & + & + & - & - & + & - & - & - & - & - & - & - & - & - & - & 3 \\
\hline Onopordum acanthium L. & + & + & + & + & + & - & + & - & + & - & - & - & + & + & - & - & 9 \\
\hline Phalacroloma annuum (L.) Dumort. & + & - & - & - & - & - & - & - & - & + & - & - & - & - & - & - & 2 \\
\hline $\begin{array}{l}\text { Phalacroloma septentrionale (Fern. et Wieg.) } \\
\text { Tzvel. }\end{array}$ & - & + & - & + & - & - & - & - & - & - & - & - & - & - & - & - & 2 \\
\hline Rudbeckia laciniata L. & + & - & - & - & - & - & - & - & - & - & - & - & - & - & - & - & 1 \\
\hline Senecio vernalis Waldst. et Kit. & + & + & - & - & + & + & + & + & - & + & + & - & - & - & - & - & 8 \\
\hline Senecio viscosus L. & + & - & - & - & - & - & - & - & - & - & - & - & - & - & - & - & 1 \\
\hline Solidago canadensis L. & + & - & - & - & - & - & - & - & - & - & - & - & - & - & - & - & 1 \\
\hline Xanthium albinum (Widd.) H. Scholz & + & - & + & + & - & - & - & - & - & - & - & - & - & - & - & - & 3 \\
\hline Xanthium ripicola Holub & - & + & - & - & - & - & - & - & - & - & - & - & - & - & - & - & 1 \\
\hline Xanthium spinosum L. & + & + & - & - & - & - & + & - & - & + & - & - & - & - & - & - & 4 \\
\hline Xanthium strumarium L. & + & + & - & - & + & - & + & + & + & + & - & - & - & - & - & - & 7 \\
\hline \multicolumn{18}{|l|}{ Balsaminaceae } \\
\hline Impatiens glandulifera Royle & + & + & - & + & - & - & - & - & - & - & - & - & - & - & - & - & 3 \\
\hline Impatiens parviflora DC. & - & - & - & - & - & + & - & - & - & - & - & - & - & - & - & - & 1 \\
\hline \multicolumn{18}{|l|}{ Berberidaceae } \\
\hline Mahonia aquifolium (Pursh) Nutt. & + & + & - & - & + & - & - & - & - & - & - & - & - & - & - & - & 3 \\
\hline \multicolumn{18}{|l|}{ Betulaceae } \\
\hline Alnus incana (L.) Moench & - & - & - & - & - & + & - & - & - & - & - & - & - & - & - & - & 1 \\
\hline Carpinus betulus L. & + & - & - & - & - & - & - & - & - & - & - & - & - & - & - & - & 1 \\
\hline \multicolumn{18}{|l|}{ Boraginaceae } \\
\hline Brunnera macrophylla (Adams) Johnst. & - & - & - & + & - & - & - & - & - & - & - & - & - & - & - & - & 1 \\
\hline Lycopsis arvensis L. & - & - & - & - & + & - & - & - & - & - & - & - & - & - & - & - & 1 \\
\hline Symphytum asperum Lepech. & - & - & - & - & + & - & - & - & - & - & - & - & - & - & - & - & 1 \\
\hline \multicolumn{18}{|l|}{ Brassicaceae } \\
\hline Armoracia rusticana Gaertn., Mey. \& Scherb. & + & + & - & - & - & - & - & - & - & - & - & - & - & - & - & - & 2 \\
\hline Brassica nigra (L.) Koch & - & - & + & - & - & - & - & - & - & - & - & - & - & - & - & - & 1 \\
\hline Brassica oleracea L. & + & - & - & - & - & - & - & - & - & - & - & - & - & - & - & - & 1 \\
\hline Bunias orientalis L. & + & + & + & + & + & + & + & + & + & + & + & - & + & - & - & - & 12 \\
\hline Camelina pilosa (DC.) N. Zing. & - & - & - & - & + & - & + & - & + & + & - & - & - & - & - & - & 4 \\
\hline Camelina sativa (L.) Crantz & - & - & - & - & + & - & - & - & - & - & - & - & - & - & - & - & 1 \\
\hline Cardaria draba (L.) Desv. & + & + & - & - & + & - & - & - & - & - & - & - & - & - & - & - & 3 \\
\hline Hesperis matronalis L. & + & - & - & + & - & - & - & - & - & - & - & - & - & - & - & - & 2 \\
\hline Hesperis pycnotricha Borb. et Degen & + & - & - & - & - & - & - & - & - & - & - & - & - & - & - & - & 1 \\
\hline Lepidium densiflorum Schrad. & + & + & + & + & - & + & + & + & + & + & + & - & + & - & - & + & 12 \\
\hline Lunaria annua L. & - & - & - & - & - & + & - & - & - & - & - & - & - & - & - & - & 1 \\
\hline Sinapis alba L. & - & - & - & - & + & - & - & - & - & - & - & - & - & - & - & - & 1 \\
\hline Sinapis dissecta Lag. & - & - & - & - & + & - & - & - & - & - & - & - & - & - & - & - & 1 \\
\hline Sisymbrium wolgense Bieb. ex Fourn. & + & + & - & - & - & - & - & - & - & - & - & - & - & - & - & - & 2 \\
\hline Thlaspi arvense L. & + & + & + & + & + & + & + & + & + & + & + & - & + & + & - & + & 14 \\
\hline
\end{tabular}




\begin{tabular}{|c|c|c|c|c|c|c|c|c|c|c|c|c|c|c|c|c|c|}
\hline \multirow{2}{*}{ Families and species } & \multicolumn{16}{|c|}{ Presence in Protected Areas } & \\
\hline & 1 & 2 & 3 & 4 & 5 & 6 & 7 & 8 & 9 & 10 & 11 & 12 & 13 & 14 & 15 & 16 & \\
\hline \multicolumn{18}{|l|}{ Cannabaceae } \\
\hline Cannabis ruderalis Janisch. & + & + & + & + & + & + & - & - & - & - & - & - & - & - & - & - & 6 \\
\hline \multicolumn{18}{|l|}{ Caprifoliaceae } \\
\hline Lonicera caprifolium $\mathrm{L}$. & - & - & - & - & + & - & - & - & - & - & - & - & - & - & - & - & 1 \\
\hline Lonicera tatarica $\mathrm{L}$. & + & + & - & + & + & + & - & - & - & - & - & - & - & - & - & - & 5 \\
\hline Sambucus ebulus L. & - & - & - & - & - & - & + & - & - & - & - & - & - & - & - & - & 1 \\
\hline Sambucus nigra $\mathrm{L}$. & + & + & - & - & + & - & - & - & - & - & - & - & - & - & - & - & 3 \\
\hline Sambucus racemosa L. & + & + & + & + & + & + & - & - & - & - & - & - & - & - & - & - & 6 \\
\hline Viburnum lantana $\mathrm{L}$. & - & - & - & - & + & + & - & - & - & - & - & - & - & - & - & - & 2 \\
\hline \multicolumn{18}{|l|}{ Caryophyllaceae } \\
\hline Agrostemma githago L. & + & - & - & - & + & - & - & - & - & - & - & - & - & - & - & - & 1 \\
\hline Dianthus barbatus L. & + & - & - & + & - & - & - & - & - & - & - & - & - & - & - & - & 2 \\
\hline Lychnis chalcedonica $\mathrm{L}$. & + & - & - & - & + & + & + & + & - & + & - & - & - & - & - & - & 6 \\
\hline Saponaria officinalis L. & + & + & + & + & + & + & - & + & + & + & - & - & - & - & - & - & 9 \\
\hline Silene dichotoma Ehrh. & + & - & + & - & + & - & + & - & + & + & - & - & + & - & - & + & 8 \\
\hline Spergula arvensis L. & + & - & - & + & + & + & - & - & - & - & - & - & - & - & - & - & 4 \\
\hline Vaccaria hispanica (Mill.) Rauschert & - & - & - & - & + & - & - & - & - & - & - & - & - & - & - & - & 1 \\
\hline \multicolumn{18}{|l|}{ Chenopodiaceae } \\
\hline Atriplex calotheca (Rafn) Fries & + & + & + & + & - & - & - & - & - & - & - & + & - & - & - & - & 5 \\
\hline Atriplex hortensis L. & - & - & - & - & + & - & + & - & - & - & - & - & - & - & - & - & 2 \\
\hline Atriplex oblongifolia Waldst. \& Kit. & - & + & - & - & + & - & - & - & - & - & - & - & - & - & - & - & 2 \\
\hline Atriplex rosea $\mathrm{L}$. & - & - & - & - & + & - & - & - & - & - & - & - & - & - & - & - & 1 \\
\hline Atriplex tatarica $\mathrm{L}$. & + & + & + & + & + & + & + & + & + & + & - & - & + & + & - & - & 12 \\
\hline Axyris amaranthoides $\mathrm{L}$. & + & + & - & - & - & - & - & - & - & - & - & - & - & - & - & - & 2 \\
\hline Chenopodium ficifolium Smith & - & + & - & - & - & - & - & - & - & - & - & - & - & - & - & - & 1 \\
\hline Chenopodium strictum Roth & - & + & - & - & + & - & + & - & - & - & - & - & - & - & - & - & 3 \\
\hline Corispermum declinatum Steph. ex Iljin & - & + & - & - & - & - & - & - & - & - & - & - & - & - & - & - & 1 \\
\hline Corispermum hyssopifolium L. & + & + & - & - & - & - & - & - & + & - & - & - & - & - & - & - & 3 \\
\hline Corispermum nitidum Schult. & - & + & - & - & - & - & - & - & - & - & - & - & - & - & - & - & 1 \\
\hline Kochia scoparia (L) Schrad. & + & - & + & - & + & - & - & - & - & - & - & - & - & - & - & - & 3 \\
\hline Salsola collina Pall. & + & - & - & - & + & - & - & - & - & - & - & - & - & - & - & - & 2 \\
\hline \multicolumn{18}{|l|}{ Convulvulaceae } \\
\hline Ipomoea purpurea (L.) Roth & + & - & - & + & - & - & - & - & - & - & - & - & - & - & - & - & 2 \\
\hline \multicolumn{18}{|l|}{ Cornaceae } \\
\hline Swida alba (L.) Opiz & + & - & - & - & + & + & - & - & - & - & - & - & - & - & - & - & 3 \\
\hline \multicolumn{18}{|l|}{ Crassulaceae } \\
\hline Sedum hybridum L. & - & - & - & + & - & - & - & - & - & - & - & - & - & - & - & - & 1 \\
\hline Sedum reflexum L. & + & - & - & - & - & - & - & - & - & - & - & - & - & - & - & - & 1 \\
\hline Sedum sexangulare L. & + & - & - & - & - & - & - & - & - & - & - & - & - & - & - & - & 1 \\
\hline Sedum spurium Bieb. & + & - & - & + & - & - & - & - & - & - & - & - & - & - & - & - & 2 \\
\hline \multicolumn{18}{|l|}{ Cucurbitaceae } \\
\hline Bryonia alba $\mathrm{L}$. & - & + & - & - & + & + & - & - & - & - & - & - & - & - & - & - & 3 \\
\hline Citrullus lanatus (Thunb.) Matsum. et Nakai & - & + & - & - & - & - & - & - & - & - & - & - & - & - & - & - & 1 \\
\hline
\end{tabular}




\begin{tabular}{|c|c|c|c|c|c|c|c|c|c|c|c|c|c|c|c|c|c|}
\hline \multirow{2}{*}{ Families and species } & \multicolumn{16}{|c|}{ Presence in Protected Areas } & \multirow[t]{2}{*}{$*$} \\
\hline & 1 & 2 & 3 & 4 & 5 & 6 & 7 & 8 & 9 & 10 & 11 & 12 & 13 & 14 & 15 & 16 & \\
\hline Echinocystis lobata (Michx.) Torr. et Gray & + & + & + & + & - & + & - & - & - & - & - & - & - & - & - & - & 5 \\
\hline Thladiantha dubia Bunge & - & - & - & + & - & - & - & - & - & - & - & - & - & - & - & - & 1 \\
\hline \multicolumn{18}{|l|}{ Cupressaceae } \\
\hline Thuja occidentalis L. & + & - & - & - & - & - & - & - & - & - & - & - & - & - & - & - & 1 \\
\hline \multicolumn{18}{|l|}{ Cuscutascese } \\
\hline Cuscuta campestris Yunck. & + & + & + & - & - & - & - & - & - & - & - & - & - & - & - & - & 3 \\
\hline \multicolumn{18}{|l|}{ Elaeagnaceae } \\
\hline Elaeagnus angustifolia L. & + & - & - & - & + & - & - & - & - & - & - & - & - & - & - & - & 2 \\
\hline Ніррорһал rhamnoides L. & + & - & - & - & + & - & - & - & - & - & - & - & - & - & - & - & 2 \\
\hline \multicolumn{18}{|l|}{ Euphorbiaceae } \\
\hline Euphorbia cyparissias L. & - & - & - & - & + & - & - & + & - & + & - & - & - & - & - & - & 3 \\
\hline \multicolumn{18}{|l|}{ Fabaceae } \\
\hline Amorpha fruticosa $\mathrm{L}$. & + & + & - & + & - & - & - & - & - & - & - & - & - & - & - & - & 3 \\
\hline Caragana arborescens Lam. & + & + & + & + & + & - & - & - & - & - & - & - & - & - & - & - & 5 \\
\hline Galega officinalis L. & - & - & - & + & - & - & - & - & - & - & - & - & - & - & - & - & 1 \\
\hline Lespedeza bicolor Turcz. & + & - & - & - & - & - & - & - & - & - & - & - & - & - & - & - & 1 \\
\hline Lupinus polyphyllus Lindl. & + & - & - & + & - & - & - & - & - & - & - & - & - & - & - & - & 2 \\
\hline Medicago minima (L.) Bartalini & - & + & - & - & - & - & - & - & - & - & - & - & - & - & - & - & 1 \\
\hline Medicago sativa $\mathrm{L}$. & + & + & + & + & + & - & - & - & - & - & - & + & - & - & + & + & 8 \\
\hline Medicago $\times$ varia T. Martyn & + & + & - & - & - & - & - & - & - & - & - & - & - & - & - & - & 2 \\
\hline Onobrychis viciifolia Scop. & - & + & - & - & - & - & - & - & - & - & - & - & - & - & - & - & 1 \\
\hline Robinia pseudoacacia L. & + & + & - & + & + & + & - & - & - & - & - & - & - & - & - & - & 5 \\
\hline Vicia sativa $\mathrm{L}$. & - & - & - & - & + & - & - & - & - & - & - & - & - & - & - & - & 1 \\
\hline Vicia villosa Roth & + & - & - & - & + & - & - & - & - & - & - & - & - & - & - & - & 2 \\
\hline \multicolumn{18}{|l|}{ Fagaceae } \\
\hline Quercus rubra L. & + & - & - & + & + & + & - & - & - & - & - & - & - & - & - & - & 4 \\
\hline \multicolumn{18}{|l|}{ Geraniaceae } \\
\hline Geranium sibiricum L. & + & + & - & - & - & + & - & - & - & - & - & - & - & - & - & - & 3 \\
\hline \multicolumn{18}{|l|}{ Grossulariaceae } \\
\hline Grossularia reclinata (L.) Mill. & + & + & - & + & + & + & - & - & - & - & - & - & - & - & - & - & 5 \\
\hline Ribes aureum Pursh & + & + & - & - & + & - & - & - & - & - & - & - & - & - & - & - & 3 \\
\hline Ribes rubrum L. & + & + & - & - & + & - & - & - & - & - & - & - & - & - & - & - & 3 \\
\hline \multicolumn{18}{|l|}{ Liliaceae } \\
\hline Hemerocallis fulva (L.) L. & + & - & - & + & - & - & - & - & - & - & - & - & - & - & - & - & 2 \\
\hline \multicolumn{18}{|l|}{ Hippocastanaceae } \\
\hline Aesculus hippocastanum L. & + & - & - & + & - & - & - & - & - & - & - & - & - & - & - & - & 2 \\
\hline \multicolumn{18}{|l|}{ Hyacinthaceae } \\
\hline Muscari neglectum Guss. & + & - & - & - & - & - & - & - & - & - & - & - & - & - & - & - & 1 \\
\hline \multicolumn{18}{|l|}{ Hydrangeaceae } \\
\hline Philadelphus latifolius Schrad. ex DC. & + & - & - & - & - & - & - & - & - & - & - & - & - & - & - & - & 1 \\
\hline \multicolumn{18}{|l|}{ Hydrocharitaceae } \\
\hline Elodea canadensis Michx. & + & + & - & + & - & - & - & - & - & - & - & - & - & - & - & - & 3 \\
\hline Hydrophyllaceae & & & & & & & & & & & & & & & & & \\
\hline
\end{tabular}




\begin{tabular}{|c|c|c|c|c|c|c|c|c|c|c|c|c|c|c|c|c|c|}
\hline \multirow{2}{*}{ Families and species } & \multicolumn{16}{|c|}{ Presence in Protected Areas } & \\
\hline & 1 & 2 & 3 & 4 & 5 & 6 & 7 & 8 & 9 & 10 & 11 & 12 & 13 & 14 & 15 & 16 & \\
\hline Phacelia tanacetifolia Benth. & + & - & - & - & + & - & - & - & - & - & - & - & - & - & - & - & 2 \\
\hline \multicolumn{18}{|l|}{ Juglandaceae } \\
\hline Juglans cinerea $\mathrm{L}$. & + & - & - & - & + & - & - & - & - & - & - & - & - & - & - & - & 2 \\
\hline Juglans mandshurica Maxim. & + & - & - & - & + & - & - & - & - & - & - & - & - & - & - & - & 2 \\
\hline \multicolumn{18}{|l|}{ Juncaceae } \\
\hline Juncus tenuis Willd. & + & - & - & + & - & - & - & - & - & - & - & - & - & - & - & - & 2 \\
\hline \multicolumn{18}{|l|}{ Lamiaceae } \\
\hline Elsholtzia ciliata (Thunb.) Hyl. & + & - & - & - & - & - & - & - & - & - & - & - & - & - & - & - & 1 \\
\hline Lamium paczoskianum Worosch. & + & + & - & - & + & - & - & - & - & - & - & - & - & - & - & - & 3 \\
\hline Nepeta cataria $\mathrm{L}$. & + & + & + & + & - & - & + & + & + & + & + & - & - & - & - & - & 9 \\
\hline Stachys anпиа (L.) L. & + & + & + & + & + & - & + & + & + & + & + & + & - & - & - & + & 12 \\
\hline \multicolumn{18}{|l|}{ Lemnaceae } \\
\hline Lemna gibba L. & + & + & + & + & - & - & - & - & - & - & - & - & - & - & - & - & 4 \\
\hline Lemna turionifera Landolt & - & - & - & + & - & - & - & - & - & - & - & - & - & - & - & - & 1 \\
\hline Wolffia arrhiza (L.) Horkel ex Wimm. & + & + & - & + & - & - & - & - & - & - & - & - & - & - & - & - & 3 \\
\hline \multicolumn{18}{|l|}{ Liliaceae } \\
\hline Tulipa $\times$ hybrida hort. & + & - & - & - & - & - & - & - & - & - & - & - & - & - & - & - & 1 \\
\hline \multicolumn{18}{|l|}{ Malvaceae } \\
\hline Abutilon theophrastii Medik. & + & + & - & - & - & - & - & - & - & - & - & - & - & - & - & - & 2 \\
\hline Alcea rosea $\mathrm{L}$. & + & - & - & - & - & - & - & - & - & - & - & - & - & - & - & - & 1 \\
\hline Malva pusilla Smith & + & + & + & + & + & + & + & - & - & + & + & - & - & - & - & - & 9 \\
\hline Malva erecta J. et C. Presl & + & - & - & - & - & - & - & - & - & - & - & - & - & - & - & - & 1 \\
\hline \multicolumn{18}{|l|}{ Oleaceae } \\
\hline Fraxinus lanceolata Borkh. & + & - & - & - & + & - & - & - & - & - & - & - & - & - & - & - & 2 \\
\hline Fraxinus pennsylvanica Marsh. & + & + & - & + & + & - & - & - & - & - & - & - & - & - & - & - & 4 \\
\hline Ligustrum vulgare L. & - & - & - & - & + & - & - & - & - & - & - & - & - & - & - & - & 1 \\
\hline Syringa vulgaris L. & + & - & - & - & + & - & - & - & - & - & - & - & - & - & - & - & 2 \\
\hline \multicolumn{18}{|l|}{ Onagraceae } \\
\hline Epilobium adenocaulon Hausskn. & + & + & - & + & - & + & + & - & - & - & - & - & - & - & - & - & 5 \\
\hline Epilobium pseudorubescens A. Skvorts. & + & + & - & - & - & - & + & - & - & - & - & - & - & - & - & - & 3 \\
\hline Oenothera biennis L. & + & + & + & + & + & + & + & - & - & - & - & - & - & - & - & - & 7 \\
\hline Oenothera villosa Thunb. & - & + & - & - & - & - & - & - & - & - & - & - & - & - & - & - & 1 \\
\hline \multicolumn{18}{|l|}{ Orobanchaceae } \\
\hline Orobanche cumana Wallr. & - & + & - & - & - & - & + & - & - & - & - & - & - & - & - & - & 2 \\
\hline Orobanche ramosa $\mathrm{L}$. & - & + & - & - & - & - & - & - & - & - & - & - & - & - & - & - & 1 \\
\hline \multicolumn{18}{|l|}{ Oxalidaceae } \\
\hline Xanthoxalis stricta (L.) Small & + & - & - & + & - & - & - & - & - & - & - & - & - & - & - & - & 2 \\
\hline \multicolumn{18}{|l|}{ Paeoniaceae } \\
\hline Paeonia lactiflora Pall. & + & - & - & - & - & - & - & - & - & - & - & - & - & - & - & - & 1 \\
\hline \multicolumn{18}{|l|}{ Papaveraceae } \\
\hline Glaucium corniculatum (L.) J.H. Rudolph & + & - & - & - & - & - & - & - & - & - & - & - & - & - & - & - & 1 \\
\hline Papaver orientale $\mathrm{L}$. & - & - & - & + & - & - & - & - & - & - & - & - & - & - & - & - & 1 \\
\hline Papaver rhoeas $\mathrm{L}$. & + & - & - & - & + & - & - & - & - & - & - & - & - & - & - & - & 2 \\
\hline
\end{tabular}




\begin{tabular}{|c|c|c|c|c|c|c|c|c|c|c|c|c|c|c|c|c|c|}
\hline \multirow{2}{*}{ Families and species } & \multicolumn{16}{|c|}{ Presence in Protected Areas } & \multirow{2}{*}{ * } \\
\hline & 1 & 2 & 3 & 4 & 5 & 6 & 7 & 8 & 9 & 10 & 11 & 12 & 13 & 14 & 15 & 16 & \\
\hline Papaver somniferum L. & + & - & - & - & - & - & - & - & - & - & - & - & - & - & - & - & 1 \\
\hline \multicolumn{18}{|l|}{ Pinaceae } \\
\hline Abies sibirica Ledeb. & + & - & - & - & + & - & - & - & - & - & - & - & - & - & - & - & 2 \\
\hline $\begin{array}{l}\text { Larix decidua Mill. subsp. polonica (Racib. } \\
\text { ex. Wóycicki) Domin }\end{array}$ & + & - & - & - & - & - & - & - & - & - & - & - & - & - & - & - & 1 \\
\hline Larix sibirica Ledeb. & + & + & - & - & + & - & - & - & - & - & - & - & - & - & - & - & 3 \\
\hline Picea abies (L.) Karst. & + & - & - & + & - & - & - & - & - & - & - & - & - & - & - & - & 2 \\
\hline Picea obovata Ledeb. & + & - & - & - & - & - & - & - & - & - & - & - & - & - & - & - & 1 \\
\hline Pinus banksiana Lamb. & + & - & - & - & - & - & - & - & - & - & - & - & - & - & - & - & 1 \\
\hline Pinus koraiensis Siebold et Zucc. & + & - & - & - & - & - & - & - & - & - & - & - & - & - & - & - & 1 \\
\hline Pinus nigra J.F. Arnold & - & + & - & - & - & - & - & - & - & - & - & - & - & - & - & - & 1 \\
\hline Pinus pallasiana D. Don & + & + & - & - & + & - & - & - & - & - & - & - & - & - & - & - & 3 \\
\hline Pinus strobus L. & + & - & - & - & + & - & - & - & - & - & - & - & - & - & - & - & 2 \\
\hline \multicolumn{18}{|l|}{ Poaceae } \\
\hline Arrhenatherum elatius (L.) J. et C. Presl & - & + & + & + & - & + & - & - & - & - & - & + & - & - & - & - & 5 \\
\hline Avena fatua $\mathrm{L}$. & - & + & + & + & + & + & + & - & - & - & - & - & - & - & - & - & 6 \\
\hline Avena sativa $\mathrm{L}$. & + & + & - & + & - & + & - & - & - & - & - & - & - & - & - & - & 4 \\
\hline Bromus japonicus Thunb. & + & + & + & + & + & + & + & - & + & + & + & + & + & + & + & + & 15 \\
\hline Bromus squarrosus L. & + & + & + & + & + & + & + & + & + & + & - & + & + & + & + & + & 15 \\
\hline $\begin{array}{l}\text { Bromus wolgensis Fisch. ex J. Jacq. f. (B. } \\
\text { squarrosus var. villosus Koch) }\end{array}$ & - & + & + & + & - & - & - & - & - & - & - & - & + & - & - & + & 5 \\
\hline Digitaria aegyptiaca (Retz.) Willd. & - & + & - & - & - & - & - & - & - & - & - & - & - & - & - & - & 1 \\
\hline Echinochloa caudata Roshev. & - & + & - & - & - & - & - & - & - & - & - & - & - & - & - & - & 1 \\
\hline Echinochloa crusgalli (L.) Beauv. & + & + & + & + & + & + & - & + & + & + & + & + & + & + & + & + & 15 \\
\hline Elymus trachycaulus (Link) Gould et Shinners & - & - & - & - & + & - & - & - & - & - & - & - & - & - & - & - & 1 \\
\hline Eragrostis minor Host & + & + & - & + & + & + & + & + & - & + & - & - & - & - & - & - & 8 \\
\hline Eragrostis pilosa (L.) Beauv. & + & + & - & + & - & + & - & - & - & - & - & - & - & - & - & - & 4 \\
\hline Hordeum distichon $\mathrm{L}$. & + & + & - & + & - & + & - & - & - & - & - & - & - & - & - & - & 4 \\
\hline Hordeum vulgare L. & + & - & - & + & - & + & - & - & - & - & - & - & - & - & - & - & 3 \\
\hline Leymus sabulosus (Bieb.) Tzvel. & - & + & + & + & - & - & - & - & - & - & - & - & - & - & - & - & 2 \\
\hline Lolium multiflorum Lam & - & - & - & - & - & + & - & - & - & - & - & - & - & - & - & - & 1 \\
\hline Lolium perenne L. & + & + & + & + & - & + & - & - & - & - & - & - & - & - & - & - & 5 \\
\hline Panicum miliaceum L. & + & + & - & + & - & - & - & - & - & - & - & - & - & - & - & - & 3 \\
\hline Phalaris canariensis L. & - & - & - & - & + & - & + & - & - & - & - & - & - & - & - & - & 2 \\
\hline Phalaroides arundinacea var. picta (L.) Tzvel. & + & - & - & - & - & - & - & - & - & - & - & - & - & - & - & - & 1 \\
\hline Psathyrostachys juncea (Fisch.) Nevski & - & - & - & - & - & - & - & - & - & + & - & - & - & - & - & - & 1 \\
\hline Secale cereale L. & + & + & - & + & - & + & - & - & - & - & - & - & - & - & - & - & 4 \\
\hline Setaria pumila (Poir.) Roem. et Schult. & + & + & + & + & + & + & + & - & - & + & - & - & + & + & - & - & 10 \\
\hline $\begin{array}{l}\text { Setaria pycnocoma (Steud.) Henrard ex Nakai } \\
\text { (S. viridis ssp. pycnocoma (Steud.) Tzvelev) }\end{array}$ & - & - & - & + & - & - & - & - & - & - & - & - & - & - & - & - & 1 \\
\hline Setaria verticillata (L.) P. Beauv. & - & - & - & + & - & + & - & - & - & - & - & - & - & - & - & - & 2 \\
\hline Setaria viridis (L.) Beauv. & + & + & + & + & + & + & + & + & - & + & + & + & - & - & + & - & 12 \\
\hline Sorghum saccharatum (L.) Moench & - & - & - & + & - & - & - & - & - & - & - & - & - & - & - & - & 1 \\
\hline Triticum aestivum L. & + & + & - & + & - & - & - & - & - & - & - & - & - & - & - & - & 3 \\
\hline
\end{tabular}




\begin{tabular}{|c|c|c|c|c|c|c|c|c|c|c|c|c|c|c|c|c|c|}
\hline \multirow{2}{*}{ Families and species } & \multicolumn{16}{|c|}{ Presence in Protected Areas } & \multirow{2}{*}{$*$} \\
\hline & 1 & 2 & 3 & 4 & 5 & 6 & 7 & 8 & 9 & 10 & 11 & 12 & 13 & 14 & 15 & 16 & \\
\hline Zea mays L. & - & + & - & - & - & - & - & - & - & - & - & - & - & - & - & - & 1 \\
\hline Zizania latifolia (Griseb.) Stapf & - & - & - & + & - & - & - & - & - & - & - & - & - & - & - & - & 1 \\
\hline \multicolumn{18}{|l|}{ Polygonaceae } \\
\hline Fagopyrum esculentum Moench & + & + & - & + & - & - & - & - & - & - & - & - & - & - & - & - & 3 \\
\hline Fagopyrum tataricum (L.) Gaertn. & - & - & + & - & - & - & - & - & - & - & - & - & - & - & - & - & 1 \\
\hline Polygonum aviculare L. & + & + & + & + & + & + & + & + & + & + & + & + & + & + & + & + & 16 \\
\hline \multicolumn{18}{|l|}{ Portulacacae } \\
\hline Portulaca oleracea L. & + & + & + & + & - & - & - & - & - & - & - & - & - & - & - & - & 4 \\
\hline \multicolumn{18}{|l|}{ Ranunculaceae } \\
\hline Aquilegia vulgaris L. & + & - & - & - & - & - & - & - & - & - & - & - & - & - & - & - & 1 \\
\hline \multicolumn{18}{|l|}{ Resedaceae } \\
\hline Reseda lutea L. & - & + & + & - & + & - & - & - & - & - & - & + & + & + & + & + & 8 \\
\hline \multicolumn{18}{|l|}{ Rosaceae } \\
\hline Amelanchier canadensis (L.) Medic & - & - & - & - & + & + & - & - & - & - & - & - & - & - & - & - & 2 \\
\hline Amelanchier spicata (Lam.) K. Koch & + & - & - & + & - & + & - & - & - & - & - & - & - & - & - & - & 3 \\
\hline Cerasus tomentosa (Thunb.) Wall. & + & - & - & + & - & - & - & - & - & - & - & - & - & - & - & - & 2 \\
\hline Cerasus vulgaris Mill. & + & + & - & + & + & - & - & - & - & - & - & - & - & - & - & - & 4 \\
\hline Chaenomeles japonica (Thunb.) Lindl. ex Spach & + & - & - & - & + & - & - & - & - & - & - & - & - & - & - & - & 2 \\
\hline Cotoneaster lucidus Schlecht. & + & - & - & - & + & - & - & - & - & - & - & - & - & - & - & - & 2 \\
\hline Crataegus coccinea $\mathrm{L}$. & - & - & - & - & + & - & - & - & - & - & - & - & - & - & - & - & 1 \\
\hline Crataegus sanguinea Pall. & + & - & - & - & + & - & - & - & - & - & - & - & - & - & - & - & 2 \\
\hline Crataegus submollis Sarg. & - & + & - & - & - & - & - & - & - & - & - & - & - & - & - & - & 1 \\
\hline $\begin{array}{l}\text { Fragaria } \times \text { ananassa (Weston) Duchesne ex } \\
\text { Rozier }\end{array}$ & - & - & - & + & - & - & - & - & - & - & - & - & - & - & - & - & 1 \\
\hline Fragaria moschata (Duchesne) Weston & - & - & - & - & - & - & + & - & - & - & - & - & - & - & - & - & 1 \\
\hline Malus baccata (L.) Borkh. & + & - & - & - & + & - & - & - & - & - & - & - & - & - & - & - & 2 \\
\hline Malus domestica Borkh. & + & + & - & + & + & - & - & - & - & - & - & - & - & - & - & - & 3 \\
\hline Padus mahaleb (L.) Borkh. & - & - & + & - & - & - & - & - & - & - & - & - & - & - & - & - & 1 \\
\hline Padus serotina (Ehrh.) Borkh. & - & - & - & - & + & - & - & - & - & - & - & - & - & - & - & - & 1 \\
\hline Physocarpus opulifolius (L.) Maxim. & + & - & - & - & + & - & - & - & - & - & - & - & - & - & - & - & 2 \\
\hline Prunus cerasifera Ehrh. & + & - & - & + & - & - & - & - & - & - & - & - & - & - & - & - & 2 \\
\hline Prunus domestica L. & + & - & - & + & + & - & - & - & - & - & - & - & - & - & - & - & 3 \\
\hline Rosa rugosa Thunb. & - & - & - & + & + & - & - & - & - & - & - & - & - & - & - & - & 2 \\
\hline Sorbaria sorbifolia (L.) A. Br. & - & - & - & - & + & - & - & - & - & - & - & - & - & - & - & - & 1 \\
\hline Spirea salicifolia L. & - & + & - & - & + & - & - & - & - & - & - & - & - & - & - & - & 2 \\
\hline \multicolumn{18}{|l|}{ Rubiaceae } \\
\hline Cruciata laevipes Opiz & + & - & - & - & - & - & - & - & - & - & - & - & - & - & - & - & 1 \\
\hline \multicolumn{18}{|l|}{ Rutaceae } \\
\hline Phellodendron amurense Rupr. & + & - & - & - & - & - & - & - & - & - & - & - & - & - & - & - & 1 \\
\hline Ptelea trifoliata $\mathrm{L}$. & + & - & - & - & + & - & - & - & - & - & - & - & - & - & - & - & 2 \\
\hline \multicolumn{18}{|l|}{ Salicaceae } \\
\hline Populus balsamifera L. & + & + & - & - & - & - & - & - & - & - & - & - & - & - & - & - & 2 \\
\hline Populus $\times$ berolinensis (C. Koch) Dipp. & + & + & - & - & - & - & - & - & - & - & - & - & - & - & - & - & 2 \\
\hline
\end{tabular}




\begin{tabular}{|c|c|c|c|c|c|c|c|c|c|c|c|c|c|c|c|c|c|}
\hline \multirow{2}{*}{ Families and species } & \multicolumn{16}{|c|}{ Presence in Protected Areas } & \multirow{2}{*}{$*$} \\
\hline & 1 & 2 & 3 & 4 & 5 & 6 & 7 & 8 & 9 & 10 & 11 & 12 & 13 & 14 & 15 & 16 & \\
\hline Populus deltoides Marsh. & + & - & - & - & - & - & - & - & - & - & - & - & - & - & - & - & 1 \\
\hline Populus italica (DuRoi) Moench & + & - & - & - & - & + & - & - & - & - & - & - & - & - & - & - & 2 \\
\hline Salix babylonica $\mathrm{L}$. & + & - & - & - & + & - & - & - & - & - & - & - & - & - & - & - & 2 \\
\hline Salix fragilis L. & + & + & + & + & + & + & - & - & - & - & - & - & - & - & - & - & 6 \\
\hline Salix purpurea L. & - & + & - & - & - & - & - & - & - & - & - & - & - & - & - & - & 1 \\
\hline Salix viminalis L. & + & + & + & + & + & - & - & - & - & - & - & - & - & - & - & - & 5 \\
\hline \multicolumn{18}{|l|}{ Schisandraceae } \\
\hline Schisandra chinensis (Turcz.) Baill. & + & - & - & - & - & - & - & - & - & - & - & - & - & - & - & - & 1 \\
\hline \multicolumn{18}{|l|}{ Scrophulariaceae } \\
\hline Veronica persica Poir. & - & + & - & - & - & - & - & - & - & - & - & - & - & - & - & - & 1 \\
\hline \multicolumn{18}{|l|}{ Solanaceae } \\
\hline Datura stramonium L. & + & + & - & + & - & - & - & - & - & - & - & - & - & - & - & - & 3 \\
\hline Lycopersicon esculentum Mill. & + & + & - & - & - & - & - & - & - & - & - & - & - & - & - & - & 2 \\
\hline Nicandra physalodes (L.) Gaertn. & + & - & - & - & - & - & - & - & - & - & - & - & - & - & - & - & 1 \\
\hline Physalis alkekengi L. & + & - & - & + & - & - & - & - & - & - & - & - & - & - & - & - & 2 \\
\hline Physalis ixocarpa Brot. ex Hornem. & - & + & - & - & - & - & - & - & - & - & - & - & - & - & - & - & 1 \\
\hline Solanum tuberosum L. & + & - & - & + & - & - & - & - & - & - & - & - & - & - & - & - & 2 \\
\hline \multicolumn{18}{|l|}{ Tiliaceae } \\
\hline Tilia euchlora C. Koch & - & + & - & - & - & - & - & - & - & - & - & - & - & - & - & - & 1 \\
\hline Tilia europaea L. & - & + & - & - & - & - & - & - & - & - & - & - & - & - & - & - & 1 \\
\hline \multicolumn{18}{|l|}{ Typhaceae } \\
\hline Typha laxmannii Lepech. & + & - & - & - & - & - & - & - & - & - & - & - & - & - & - & - & 1 \\
\hline \multicolumn{18}{|l|}{ Ulmaceae } \\
\hline Ulmus pumila L. & + & + & + & + & + & - & - & - & - & - & - & - & - & - & - & - & 5 \\
\hline \multicolumn{18}{|l|}{ Urticaceae } \\
\hline Urtica cannabina L. & - & - & - & + & - & - & - & - & - & - & - & - & - & - & - & - & 1 \\
\hline \multicolumn{18}{|l|}{ Vitaceae } \\
\hline Parthenocissus inserta (A. Kern.) Fritsch & - & + & - & + & - & - & - & - & - & - & - & - & - & - & - & - & 2 \\
\hline Parthenocissus quinquefolia (L.) Planch. & + & - & - & - & + & + & - & - & - & - & - & - & - & - & - & - & 3 \\
\hline Vitis amurensis Rupr. & + & - & - & - & + & - & - & - & - & - & - & - & - & - & - & - & 2 \\
\hline \multicolumn{18}{|l|}{ Zigophyllaceae } \\
\hline Tribulus terrestris L. & - & + & - & - & - & - & - & - & - & - & - & - & - & - & - & - & 1 \\
\hline
\end{tabular}

1 - Voronezh State Nature Biosphere Reserve; 2 - Khoper State Nature Reserve; 3 - State open-air museum of architecture and archeology «Divnogorye»; 4 - State federal-level nature sanctuary «Voronezhsky»; 5 - State federal-level nature sanctuary «Kamennaya Steppe»; 6 - Regional-level nature sanctuary «Voronezh uphill oakery»; Regional-level natural monuments: 7 - Khrenovskaya Steppe; 8 - Krasnyanskaya Steppe; 9 - Steppe Hillslopes by Vladimirovka settlement; 10 - Volokonovskaya Steppe; 11 - Khripunskaya Steppe; 12 - Melovaya Sosna; 13 - Golik; 14 - Maydan; 15 - Krutzy; 16 - Kreyda na Zapadne. * - Number of Protected Areas, where the species was detected. 


\title{
ЧУЖЕРОДНЫЕ ВИДЫ В ЛОКАЛЬНЫХ ФЛОРАХ ПРИРОДНО- ЗАПОВЕДНОГО ФОНДА ВОРОНЕЖСКОЙ ОБЛАСТИ (РОССИЯ)
}

\author{
Е. А. Стародубцева ${ }^{1}$, А. Я. Григорьевская ${ }^{2}$, Л. А. Лепешкина ${ }^{2}$ О. С. Лисова ${ }^{3}$ \\ ${ }^{1}$ Воронежский государственный природный биосферный заповедник имени В.М. Пескова, Россия \\ e-mail:starodbtsv@gmail.com \\ ${ }^{2}$ Воронежский государственный университет, Россия \\ e-mail: grigaya@mail.ru,lilez1980@mail.ru \\ ${ }^{3}$ Воронежский государственный лесотехнических университет илени Г.Ф. Морозова, Россия \\ e-mail: ospopova@yandex.ru
}

Были изучены чужеродные фракции локальных флор природно-заповедного фонда Воронежской области, расположенной на границе лесостепной и степной зон. Были выбраны 16 модельных особо охраняемых природных территорий (ООПТ), имеющих различный природоохранный статус и различные размеры территорий. В статье предпринята попытка оценить: а) степень биологического загрязнения флор ООПТ, охраняющих лесостепные и степные экосистемы; б) особенности адвентивных фракций флор ООПТ различных категорий. Дана характеристика ООПТ в отношении возможностей и условий для инвазии чужеродных видов сосудистых растений. Адвентивная фракция флор ООПТ включает 262 таксона: 255 видов, 5 гибридов, 1 подвид, 1 разновидность, относящихся к 178 родам и 66 семействам. Для типологического анализа чужеродные виды были разделены на группы по времени заноса, способу заноса и степени натурализации. Доля чужеродных видов в составе локальных флор ООПТ в среднем составляет $11.1 \%$ (от 4.4\% до 16.8\%). Если учитывать только стабильные элементы флоры (без эфемерофитов и колонофитов), степень загрязнения локальных флор ООПТ в среднем составляет $6.1 \%$ (от $3.5 \%$ до $8.9 \%$ ). Наибольшее число адвентивных видов отмечено во флорах государственных заповедников и государственных заказников, региональные ООПТ характеризуются меньшей долей чужеродных растений. Анализ способов заноса чужеродных видов показал, что большой вклад в пополнение чужеродной флоры на ООПТ вносит деятельность человека по интродукции растений: $31.7 \%$ адвентов - это «беглецы из культуры», 15\% чужеродных видов были целенаправленно посажены на этих ООПТ. Во флорах ООПТ отмечено 19 видов-трансформеров, из них 11 являются ксенофитами, 8 видов - эргазиофитами. В результате проведенного исследования сделан вывод о необходимости проведения практических работ по управлению процессом инвазии адвентивных растений на территориях государственных заповедников.

Ключевые слова: инвазии, особо охраняемые природные территории, природно-заповедный фонд, чужеродная флора, чужеродные виды растений 